\title{
Quantitative assessment of bacterial and fungal degradation of glucose and cellulose
}

Rene N. Miller

Follow this and additional works at: https://researchrepository.wvu.edu/etd

\section{Recommended Citation}

Miller, Rene N., "Quantitative assessment of bacterial and fungal degradation of glucose and cellulose" (2018). Graduate Theses, Dissertations, and Problem Reports. 7215.

https://researchrepository.wvu.edu/etd/7215

This Thesis is protected by copyright and/or related rights. It has been brought to you by the The Research Repository @ WVU with permission from the rights-holder(s). You are free to use this Thesis in any way that is permitted by the copyright and related rights legislation that applies to your use. For other uses you must obtain permission from the rights-holder(s) directly, unless additional rights are indicated by a Creative Commons license in the record and/ or on the work itself. This Thesis has been accepted for inclusion in WVU Graduate Theses, Dissertations, and Problem Reports collection by an authorized administrator of The Research Repository @ WVU. For more information, please contact researchrepository@mail.wvu.edu. 
Quantitative assessment of bacterial and fungal degradation of glucose and cellulose

\author{
Rene N. Miller
}

Thesis submitted to the Davis College of Agriculture, Natural Resources and Design at West Virginia University in partial fulfillment of the requirements for the degree of Master of Science in Applied and Environmental Microbiology

\author{
Ember Morrissey, Ph.D., Chair \\ Daniel Panaccione, Ph.D. \\ Mathew Kasson, Ph.D. \\ Division of Plant and Soil Sciences \\ Morgantown, West Virginia \\ 2018
}

Keywords: decomposition, carbon cycle, cellulose, glucose, fungi, bacteria, soil Copyright 2018 Rene N Miller 


\section{Abstract \\ Quantitative assessment of bacterial and fungal degradation of glucose and cellulose Rene Miller}

Fungi are known for having metabolic capabilities that allow them to decompose complex organic material and are abundant in the organic soil horizon. The mineral horizon has a greater proportion of bacteria. These trends suggest that fungi are the predominate decomposers of complex polymeric substrates while bacteria focus on simpler substrates. However multiple strains of cellulose degrading bacteria have been identified making the relative contribution of these groups to decomposition less clear. The goal of this research was to quantify the assimilation of cellulose and glucose derived carbon by bacterial and fungal taxa thus revealing their decomposition activity. To address this objective, we examined bacterial and fungal communities from soils with differing carbon substrate inputs by sampling the Detritus Input and Removal Treatment (DIRT) plots in Harvard Forest (Petersham, MA). We examined soils that have received twice the normal amount of leaf litter (double litter), had no leaf litter (no litter), or had normal litter inputs (control). We measured the decomposition of glucose and cellulose by incubating soils with ${ }^{13} \mathrm{C}$-labeled substrates. Assimilation of substrates by microbial taxa was assessed by quantitative stable isotope probing. This method measures the incorporation of isotopically labeled (i.e. ${ }^{13} \mathrm{C}$ ) compounds into the DNA of microorganisms. The rate of glucose decomposition was greater than that of cellulose regardless of treatment, with the majority of mineralization occurring in the first two weeks. The rate of decomposition varied across treatments. Both microbial groups showed significant ${ }^{13} \mathrm{C}$ incorporation from glucose and cellulose. On average fungal operational taxonomic units (OTUs) had a higher ${ }^{13} \mathrm{C}$ excess atom fraction (EAF) compared to bacterial OTUs for both substrates. A significant number of bacterial OTUs had little to no ${ }^{13} \mathrm{C}$ EAF suggesting that those OTUs may be dormant or utilizing alternative substrates. The metabolically active bacterial OTUs may be important in cellulose degradation and competitive in glucose assimilation. Bacterial OTUs ${ }^{13} \mathrm{C}$ EAF was not significantly different between substrates and across treatments, whereas fungal OTUs ${ }^{13} \mathrm{C} \mathrm{EAF}$ varied. Substrate usage by bacteria was not impacted by environmental variance, whereas fungal usage may vary. 


\section{Acknowledgements}

I would like to thank my advisor, Dr. Ember Morrissey for giving me this opportunity to do my own research and assist with multiple projects. Your help and support throughout my time here at WVU is greatly appreciated. Also, I would like to thank my committee members Dr. Daniel Panaccione and Dr. Matt Kasson, my family and office/lab members for your guidance, support and encouragement in my graduate career and life. Lastly, I would like to thank Mel Knorr for her assistance with sampling and PLFA analysis. 
Table of Contents

Abstract ii

Acknowledgements $\quad$ iii

List of tables $\quad$ V

List of figures $\quad$ vi

List of abbreviations vii

Introduction 1

Methods 4

Field sites and sample collection $\quad 4$

Soil analysis $\quad 5$

Microbial community composition

Stable isotope probing incubations $\quad 5$

$\begin{array}{ll}\text { Enzymatic activity } & 6\end{array}$

DNA analyses $\quad 6$

$\begin{array}{ll}\text { Sequencing of 16S \& 18S rRNA genes } & 7\end{array}$

Data analysis $\quad 9$

Results $\quad 10$

$\begin{array}{ll}\text { Discussion } & 12\end{array}$

$\begin{array}{ll}\text { Soil characteristics } & 12\end{array}$

$\begin{array}{ll}\text { Enzymatic activity and respiration } & 13\end{array}$

qSIP 14

$\begin{array}{ll}\text { Conclusion } & 17\end{array}$

$\begin{array}{ll}\text { Tables } & 18\end{array}$

Figures $\quad 22$

References $\quad 27$ 


\section{List of tables}

Table

Page

1 Soil characteristics of treatment plots

18

2 Effects of litter treatment on the mean relative abundance of bacterial and fungal phospholipid fatty acids

3 Effect of litter treatment on mean enzymatic rate of BG and $\mathrm{CBH} \quad 20$

4 Richness of OTUs observed within fungal orders and phyla in the different litter treatments 


\section{List of figures}

Figure

Page

1 The effect of historical detrital input on cellulose, glucose and natural

decomposition.

2 Fungal OTUs-specific atom fraction excess of ${ }^{13} \mathrm{C}$ in the glucose and cellulose incubations.

3 Bacterial OTUs-specific atom fraction excess of ${ }^{13} \mathrm{C}$ in the glucose and cellulose incubations.

4 Histograms of atom fraction excess of ${ }^{13} \mathrm{C}$ for fungal and bacterial OTUs in the glucose and cellulose incubations.

5 Spearman correlation of atom fraction excess of ${ }^{13} \mathrm{C}$ across treatments. 


\section{List of abbreviations}

SOC- soil organic carbon

SOM- soil organic matter

OTU- operational taxonomic unit

qSIP- quantitative stable isotope probing

qPCR- quantitative polymerase chain reaction

EAF- excess atom fraction

WAD- weighted average density

WHC- water holding capacity

PLFA- phospholipid fatty acid analysis

gOM- per gram organic matter 


\section{Introduction}

Soil is a large carbon (C) pool. It stores 4.5 times the $\mathrm{C}$ contained in vegetation (Lal, 2004). Human activities have reduced soil organic carbon (SOC) stocks; since the industrial revolution soil has released $78 \pm 12 \mathrm{Pg}$ of $\mathrm{C}$ into the atmosphere (Lal, 2004). This release of $\mathrm{C}$ is at an increased rate than before the industrial revolution (McKinley et al, 2011) and contributes to global climate change. Management of agricultural and natural ecosystems may mitigate rising carbon dioxide $\left(\mathrm{CO}_{2}\right)$, for instance by reducing tillage by farmers or the use of forests to sequester C (Bowden et al, 2014; Fekete et al., 2014). The possibility of using forests to sequester $\mathrm{C}$ is a newer proposal. Sequestration of $\mathrm{C}$ is possible because not all of the $\mathrm{C}$ entering soil is labile and respired by microorganisms; some of it is recalcitrant and remains in the soil for thousands of years contributing to the stored C pool (Lal, 2004; McKinley et al, 2011; Fontaine et al, 2007). This sequestering of $\mathrm{C}$ may reduce the amount of $\mathrm{CO}_{2}$ in the atmosphere. Models can predict the processing of $\mathrm{C}$ in soil and its release into the atmosphere. However, the majority of models describe the activities of microorganisms using only one variable that fails to capture the complexity of microbial communities and soil organic matter (SOM) chemistry. This "black box" approach is not an accurate representation of what occurs in soil as a result of microorganisms. Soils are biodiverse and the roles of individual microbial operational taxonomic units (OTUs) are debated (Bezemer et al, 2010; Philippot et al, 2013; Torsvik, V., \& Øvreås, L., 2002). SOM is similarly complex with compounds existing along a spectrum from labile to recalcitrant (de Vries \& Caruso, 2016; Contrufo et al., 2013; Lehmann \& Kleber, 2015). The "black box" or a single variable model to describe microorganisms' interaction with the C cycle is inadequate (Allison, 2012; Rey et al, 2005). For instance, models by Allison (2012) and Rey et al. (2005) could not fully predict leaf litter decay or changes in production of $\mathrm{CO}_{2}$ from soil. This inadequacy could be addressed if more was known about microbial community composition and interactions (Allison, 2012), and substrate utilization and how it varies between soil types and C inputs. The taxonomic groups that make up the soil microbial communities can vary in their response to plant litter composition, nutrient content, soil moisture and C quality (Contrufo et al., 2013; Rousk \& Frey, 2015; Rey et al, 2005). With these factors that can change community response and composition, it is necessary to understand which organisms consume dominant substrates because soil microbial community composition may directly impact the $\mathrm{C}$ cycle (Zhang et al., 2014; Lopez-Lozano et al. 2013). For instance, differences in microbial 
biodiversity can influence rates of litter decay, and soil respiration (Allison, 2012; Evans \& Wallenstein, 2013; Waring et al., 2013). Having an estimate of respiration rates by a microbial community in a mixed-hardwood forest soil and the communities' use of SOC will allow C decomposition models to predict future $\mathrm{CO}_{2}$ concentrations. This may allow for a more precise prediction of soil C decomposition.

One primary controller of decomposition rates is litter quality (Contrufo et al., 2013; Couteaux et al, 1995; Sariyildiz \& Anderson, 2003). Labile substrates that are rapidly decomposed by microorganisms are considered to be of higher quality than more recalcitrant substrates that degrade slowly (Contrufo et al., 2013; Averill et al.; 2014). The quality of SOC can change due to quantity of leaf litter inputs. For example, Rousk \& Frey (2015) found that increasing the amount of litter inputs resulted in a higher quality $\mathrm{C}$ and an increased $\mathrm{C}: \mathrm{N}$ ratio than in treatments without litter inputs. This change in soil C could alter microbial community composition (Morrissey et al., 2014; Kramer \& Gleixner, 2008).

Soil microbial communities are dominated by fungi and bacteria. They are integral parts of the decomposition of $\mathrm{C}$ substrates in soil. In forests, fungi are dominant at the surface of soil (the organic horizon) and bacteria below the surface layer (the mineral horizon, Fierer et al, 2003; Šnajdr et al., 2008; Baldrian et al., 2012). C substrate usage of these groups is considered to differ; bacteria generally decompose easily available substrates like glucose and exhibit high turnover rates (de Vries \& Caruso, 2016, Graaf et al, 2010); whereas, fungal communities predominately decompose complex polymers like cellulose and lignin (Graaf et al, 2010, Rousk \& Frey, 2015). However, this theory of substrate usage is obscured by the identification of cellulose degrading bacteria (el Zahar Haichar et al., 2007; Lu et al., 2005; Ransom-Jones et al., 2012) and the capability of fungal OTUs to have a more efficient C \& N cycling (de Vries \& Caruso, 2016; Hunt et al, 1987; De Ruiter, 1993; de Vries et al, 2011). This efficient cycling allows fungi to utilize the labile substrates and produce enzymes to degrade recalcitrant substrates, which increases competition for both substrates. Fungi can utilize labile C substrates and exhibit enhanced growth in response to abundant leaf litter (Rousk \& Frey, 2015; de Vries \& Caruso, 2016). Lack of understanding of which bacterial and fungal OTUs utilize cellulose and glucose in mineral soil; limits our ability to understand and predict decomposition rates and soil C storage. 
In this study we used quantitative Stable Isotope Probing (qSIP, Hungate et al. 2015) to identify which microbial OTUs are decomposing cellulose and glucose. This method quantifies the assimilation of a labeled-substrate by individual microbial OTUs. The assimilation of the labeled-substrate can be done by indirect or direct substrate usage. An OTU that has indirect substrate usage would have assimilation of the cellulose by product and does not produce the enzymes to degrade the $\mathrm{C}$ substrate. Microbial OTUs that produce enzymes to degrade the substrate and assimilate the product is an example of direct substrate usage. This technique works by incubating environmental samples with a ${ }^{13} \mathrm{C}$ labeled substrate. The substrate is assimilated into biomass including DNA or respired. The DNA from the incubated soil samples are extracted and separated based on density. This is done by a $\mathrm{CsCl}$ gradient and ultracentrifugation, which allows for the formation of multiple density fractions with nucleic acids depending on the extent of ${ }^{13} \mathrm{C}$ incorporation into DNA. The phylogenetic marker (16S rRNA and 18S rRNA) genes are quantified by quantitative polymerase chain reaction (qPCR) and the source of the products are then identified by Illumina sequencing. The qPCR allows for quantification of the abundance of the gene, while the sequencing allows for identification of the microbial OTUs present. To measure the amount of the stable isotope incorporated by an organism a weighted average density (WAD) is calculated. This is done by summing products of density and the phylotype's gene abundance for all the fractions taken from the centrifuge tube. The density of the organism's DNA after incubation with the labeled substrate is then compared to its density in the control incubation that did not have a stable isotope. This allows for changes in density to be observed. Microorganisms do not assimilate all of the substrate into biomass as they respire a fraction as $\mathrm{CO}_{2}$ and some substrate remains in the soil. The ${ }^{13} \mathrm{C}$ that was incorporated into DNA allows for a quantitative measure of OTU specific utilization in organisms that decompose SOC.

To determine if historical changes in organic matter inputs to the soil alter $\mathrm{C}$ substrate usage and community composition, we collected soil from the Detritus Input and Removal Treatments (DIRT) within the Harvard Forest Long Term Ecological Research (LTER) station (Petersham, MA). The DIRT plots were established in 1990 and have multiple treatments. However, for our research we looked at three treatments with varying leaf litter input; the control (normal litter input), double litter (twice the amount of normal leaf litter received) and no litter (litter removed). The treatment plots exhibited differences in SOM quantity and chemistry. For 
instance, the double litter treatment had double the organic horizon of the control and the no litter had negligible amounts. Nadelhoffer et al. (1999) observed that litter input contributed to changes in concentrations of $\mathrm{C}$ and $\mathrm{N}$ present in the soil and changes in respiration between treatments.

Here we used qSIP to further understand the function of different microbes in the C cycle using qSIP. There were two objectives for this experiment: 1 . quantify ${ }^{13} \mathrm{C}$ assimilation by bacterial and fungal OTUs from glucose and cellulose, and 2. assess patterns in substrate usage and rates of $\mathrm{C}$ degradation across litter input treatments.

\section{Methods}

\section{Field sites and sample collection}

Soil samples were collected from the Harvard Forest DIRT Experimental Plots located in Petersham, MA on December 2, 2016. The plots are located in a century old, mixed hardwood forest consisting of northern red oak (Quercus borealis), red maple (Acer rubrum) and paper birch (Betula papyrifera). Further site description can be found in Bowden et al. (1993). The plots were established in 1990 and had been maintained for 26 years at the time of sampling. The samples were collected from a subset of the DIRT treatments: control, double litter, and no litter. The experimental plots $(3 \times 3 m)$ are randomly placed within a block. Each block has one of each of the litter treatments randomly located in it and the block is replicated three times. The plots range in the amount of leaf litter additions. The control treatment has the normal amount of leaf litter fall that occurs naturally throughout the year. Double litter treatment has twice the amount of the leaf litter fall that occurs in a year, so twice the litter that falls on the control treatment plots. This addition is completed by the removal of the leaf litter from a no litter plot and its transfer to its paired double litter plot within the block. A total of 10 cores were taken from each plot and were 1 inch in diameter. The visible organic horizon was measured and removed; the top $10 \mathrm{~cm}$ of the mineral horizon was collected. The cores from the individual plots were homogenized and stored at $\sim 4^{\circ} \mathrm{C}$ for 24 hours prior to soil analyses and 72 hours prior to the experimental incubations were conducted. The initial time was the start of the soil incubations.Soil was set aside for DNA analysis at this initial time, so the initial microbial community could be analyzed before incubation of the substrates. 


\section{Soil analysis}

The percent soil moisture was determined by the addition of $10 \mathrm{~g}$ of soil into a tin and allowed to dry for 24 hours at $65^{\circ}$. After the soil is dried and re-weighed, the grams of water present in the soil was divided by the soil wet weight. The percent SOM was determined as loss on ignition by combusting dried samples at $400^{\circ \mathrm{C}}$ for 15 hours in a Lindburg blue $\mathrm{M}$ muffler furnace (Thermo Scientific, Waltham, MA, USA). The C:N ratio was determined by combustion of around $200 \mathrm{mg}$ of dry soil with a vario MAX cube (Elementar, Ronkonkoma, NY). Lastly, the water-holding capacity (WHC) was determined by the addition of approximately $10 \mathrm{~g}$ of soil to filter paper over a container with $10 \mathrm{~mL}$ of water added. The water was gravitationally filtered into the container and the entire apparatus was weighed.

\section{Microbial community composition}

Phospholipid fatty acid (PLFA) analysis was completed on the original nine soil samples (three per treatment). A modified Bligh and Dyer (1959) extraction procedure (White et al, 1979, Guckert et al. 1985) was used to include a single phase solvent system (chloroform) modified with a phosphate buffer. Further steps were taken to convert the viable lipid extracts to fatty acid methyl esters (FAMEs). Purified FAMEs after being brought to volume with hexane were injected onto a Varian 3800 FID GC. Identification and quantification of FAMEs were based on retention time data with known standards from Matreya, LLC (State College, PA). The fungal

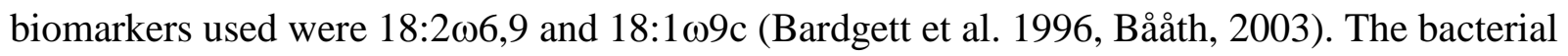
biomarkers were made up of four different groups of fatty acids, i15:0, a15:0, i16:0, i17:0 and

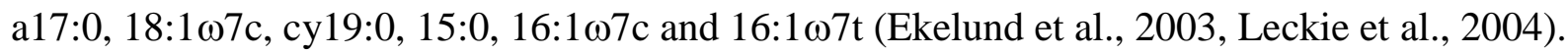

\section{Stable isotope probing incubations}

Within 72 hours of collection, samples were homogenized and $21 \mathrm{~g}$ subsamples were added to $950 \mathrm{~mL}$ mason jars. Subsamples were amended with 99 atom percent ${ }^{13} \mathrm{C}$ glucose, 97 atom percent ${ }^{13} \mathrm{C}$ cellulose, or water (control). Cellulose was purchased from IsoLife (Wageningen, NL) and the glucose was purchased from Isotec (Miamisburgh, $\mathrm{OH}$ ). The substrates were added at concentrations of $400 \mu \mathrm{g}{ }^{13} \mathrm{C}-\mathrm{C}$ g soil ${ }^{-1}$ in sterile water sufficient to bring the soils WHC to $60 \%$. The mineralization of the substrate was quantified through ${ }^{13} \mathrm{CO}_{2}$ production rates in a similar fashion as in Morrissey et al. (2015). Briefly, $60 \mathrm{~mL}$ of head space 
gas was sampled through septa in the lids every 2 to 3 days for 42 days. After each sampling, the incubation jars were aerated for 10 minutes. For the measurement of total C production $10 \mathrm{~mL}$ of the gas was removed and quantified with a LI-COR 6400XT (LI-COR, Lincoln, Nebraska, USA) and $50 \mathrm{~mL}$ was used in quantifying ${ }^{13} \mathrm{C}$ production with a Picarro Cavity Ring-Down Spectrometer (Picarro Inc., Sunnyvale, California, USA). Mineralization of each substrate was determined by the ${ }^{13} \mathrm{C}$ produced in $\mathrm{CO}_{2}$ and the known concentration of the amount of substrate added and the natural soil C. The isotopic mass balance equation was used:

$$
{ }^{13} \mathrm{C}=\mathrm{C}_{\text {total }}\left(\delta^{13} \mathrm{C}_{\text {total }}-\delta^{13} \mathrm{C}_{\text {soil carbon }}\right) /\left(\delta^{13} \mathrm{C}_{\text {carbon substrate }}-\delta^{13} \mathrm{C}_{\text {soil carbon }}\right)
$$

The fraction of ${ }^{13} \mathrm{C}$-labeled substrate remaining in the soil was calculated by subtracting the cumulative ${ }^{13} \mathrm{C}$-labeled substrate mineralized to $\mathrm{CO}_{2}$ from the total labeled substrate to the jar. Soil was removed from the incubations for analysis on days 0, 7, 21 and 42 for enzymatic assays and DNA analysis. Soil for the DNA analysis was immediately frozen prior to extraction, while soil for enzymes was stored at $\sim 4^{\circ \mathrm{C}}$ for 24 hours or less. The DNA samples used for qSIP and further analysis was taken from day 0 for all incubations and day 7 in the glucose incubations and day 21 for cellulose.

\section{Enzymatic activity}

Extracellular enzyme activity was measured for all incubations on day 0, 7, 21 and 42. The enzymes measured to identify degradation of the $C$ substrates were $\beta$-1,4-glucosidase (BG, E.C. 3.2.1.21) and 1,4- $\beta$-cellobiosidase (CBH, E.C.3.2.1.91). The activity of these enzymes was measured by artificial substrates that were linked to methylumbelliferone (MUB, Sigma-Aldrich Co., St. Louis, MO, USA) for fluorescence. The protocol for enzyme activity was from Neubauer et al. (2013). The only modification was the soil slurries were prepared by adding $0.25 \mathrm{~g}$ of soil to $25 \mathrm{~mL}$ of deionized water and sonicated at $15 \mathrm{~W}$ for 2 minutes with a Tissue Tearer Model 985-370 (Biospec Products, Bartlesville, OK, USA).

\section{DNA analyses}

Total soil DNA was extracted with the PowerSoil DNA Isolation Kit (MoBio, Carlsbad, CA) using their protocol with some modification. The modifications were after adding the C1 solution the tubes were heated at $70^{\circ} \mathrm{C}$ for 10 minutes. After the additions of C2 and C3, samples were incubatedfor 5 minutesinstead of 10 minutes, and solution C6 was heated and added in two 
$50 \mu \mathrm{L}$ aliquots. For qSIP, DNA was added to CsCl with a density of approximately $1.66 \mathrm{~g} \mathrm{~mL}^{-1}$. This is because the density of DNA can range from 1.64-1.68 $\mathrm{g} \mathrm{mL}^{-1}$ for bacteria (Zahar et al., 2007). After the $\mathrm{CsCl}$ addition, samples were centrifuged in OptiSeal centrifuge tubes using a TLA-100 rotor in an Optima Max ultracentrifuge (Beckman Coulter Life Sciences, Indianapolis, Indiana, USA) at 60,000 rpm for 72 hours at $18^{\circ} \mathrm{C}$. The resulting gradient was fractionated with 20 drops into each tube, which is approximately $200 \mu \mathrm{L}$. The density of each fraction was measured with a Pocket Refractometer Pal-1 (Bellevue, WA, USA). The DNA was separated from the CsCl using isopropanol precipitation similar to Hungate et al. (2015). The DNA was resuspended in molecular biology grade water (Bicca, Arlington, TX, USA) and quantified in each density fraction. DNA was quantified by PicoGreen (Molecular Probes, Inc., Eugene, OR) fluorescence. The total number of bacterial 16S rRNA and fungal 18S rRNA gene copies in each density fraction were determined by qPCR. All fractions were analyzed in triplicate in $15 \mu \mathrm{L}$ reactions. The reactions (15 $\mu \mathrm{L}$ ) consisted of $2 \mu \mathrm{L}$ of DNA template and $13 \mu \mathrm{L}$ of master mix. The 16S rRNA reactions consisted of $2 \mu \mathrm{L}$ of DNA template, $0.2 \mu \mathrm{M}$ forward (515F 5'-GTGYCAGCMGCCGCGGTAA--3') and reverse (806R 5'--GGACTACNVGGGTWTCTAAT-3') primers (Caporaso et al., 2011), $7.5 \mu \mathrm{L}$ Syber Green Master Mix (BIO-RAD, Hercules, CA, USA) and molecular grade water. Thermal cycling conditions were denaturation at $95^{\circ} \mathrm{C}$ for 2 minutes, followed by 40 cycles of $95^{\circ} \mathrm{C}$ for 30 seconds, $55^{\circ} \mathrm{C}$ for 30 seconds and $72^{\circ} \mathrm{C}$ for 60 seconds. The 18S rRNA reaction amplified the V9 region and the reaction contained $0.4 \mu \mathrm{M}$ forward (1380F 5'-CCCTGCCHTTTGTACACAC--3') and reverse (1510R 5'-CCTTCYGCAGGTTCACCTAC--3') primers (Amaral-Zettler et al, 2009), $7.5 \mu \mathrm{L}$ Syber Green

and molecular grade water. The cycling conditions were: one step at $98^{\circ} \mathrm{C}$ for 3 minutes, followed by 40 cycles of $98^{\circ} \mathrm{C}$ for 45 seconds, $60^{\circ} \mathrm{C}$ for 45 seconds and $72^{\circ} \mathrm{C}$ for 30 seconds. The qPCR reactions were completed on a Thermofischer Quantstudios Real-Time PCR system (Thermo Fisher, Waltham, MA)

\section{Sequencing of $16 S \& 18 S$ rRNA genes}

For each sample, density fractions that had a density greater than $1.63 \mathrm{~g} \mathrm{~mL}^{-1}$ and at least $1 \%$ of bacterial 16S rRNA genes were sequenced using Illumina adapted 515F and 806R 16S rRNA primers and the Schloss lab protocol (Kozich, et al. 2013). For 18S rRNA gene sequencing, fractions that had a density greater than $1.62 \mathrm{~g} \mathrm{~mL}^{-1}$ and at least $1 \%$ total $18 \mathrm{~S}$ rRA 
gene copies were amplified using EukV4F and EukV4R adapted primers that target the V4 region adapter (in bold) attached to (EukV4F 5'-

ACACTGACGACATGGTTCTACACCAGCASCYGCGGT-AATTCC--3') and (EukV4R 5' TACGGTAGCAGAGACTTGGTCTACTTTCGTTCTT-GATYRA--3') described in Stoeck et al. (2010). PCR reactions (25 uL) contained $1 \mu \mathrm{L}$ DNA template, $5 \mu \mathrm{L}$ high fidelity buffer (Thermo Scientific, Waltham, MA, USA), $0.5 \mu \mathrm{L} 10 \mathrm{mM}$ dNTPs, $17.25 \mu \mathrm{L}$ molecular grade water, $0.50 \mu \mathrm{L}$ of each primer at an initial concentration of $10 \mu \mathrm{M}$ and $1 \mathrm{U}$ of Phusion HighFidelity DNA Polymerase (Waltham, MA, USA). The thermocycling conditions used were: initial denaturation at $95^{\circ} \mathrm{C}$ for 5 minutes, followed by 35 cycles of denaturation at $95^{\circ} \mathrm{C}$ for $15 \mathrm{~s}$, annealing at $65^{\circ} \mathrm{C}$ for $30 \mathrm{~s}$ and amplification/extension at $68^{\circ} \mathrm{C}$ for $1 \mathrm{~min}$ with a final elongation at $72^{\circ} \mathrm{C}$ for 10 min on a BioRad 2100 thermal cycler (BioRad, Hercules, CA, USA). The PCR product was quantified by PicoGreen (Molecular Probes, Inc., Eugene, OR) fluorescence and quality checked on a $2 \%$ agarose gel (VWR, Radnor, PA, USA) that ran for 1 hour at 130V. A secondary amplification (15 $\mu \mathrm{L}$ ) was done by Michigan State University’s sequencing facility, this 'tailing' reaction added the Illumine adaptors (Illumina Inc., San Diego, CA, USA). The reaction utilized 7.50 $\mu \mathrm{L}$ 2.0X Hot Master Mix (New England biolabs, Ipswich, MA, USA), 5.50 $\mu \mathrm{L}$ DI water, $6 \mu \mathrm{M}$ primer mix and $1 \mu \mathrm{L}$ of the EukV4 amplicon. The thermocycling conditions used were: initial denaturation at $95^{\circ}$ for 3 minutes, followed by 15 cycles of denaturation at $95^{\circ} \mathrm{C}$ for $15 \mathrm{~s}$, annealing at $60^{\circ} \mathrm{C}$ for $30 \mathrm{~s}$ and amplification/extension at $72^{\circ} \mathrm{C}$ for $1 \mathrm{~min}$ with a final elongation at $72^{\circ} \mathrm{C}$ for 3min. Both bacterial 16S rRNA and fungal 18S rRNA amplification products were batch normalized with the Invitrogen SequealPrep DNA normalization plates. The products recovered were pooled and cleaned using Ampure XP magnetic beads. The pools were quality checked and quantified with Thermo Fischer Qubit dsDNA HS (Waltham, MA, USA), Agilent Bioanalyzer DNA 1000 (Santa Clara, CA, USA) and Kapa Illumina Library Quantification qPCR assays (Boston, MA, USA). Individual pools were loaded onto a MiSeq standard v2 flow cell and sequenced in a 2x250bp paired end format that utilized a MiSeq v2 500 cycle reagent cartridge. Index 1 primers were added to appropriate wells and complemented the bacterial 16S-V4 primers 515F/806R or the fungal amplicons Fluidigm CS1/CS2 oligo tags. Illumina Real Time Analysis (RTA) v.1.18.54 was used for base calling and RTA output was demultiplexed and converted to FastQ format with Illumina Bcl2fastq v2.19.1. 


\section{Data analysis}

The unit of measurement for respiration and enzymatic activity was per gram organic matter (gOM). This unit of measurement was used to standardize for a variation in substrate availability in the soil. All statistical analyses were done in R (version 3.4.0). One-way ANOVAs were completed on all soil characteristic data and PLFAs and used the aov function (Chambers et al., 1992). Two way-repeated measures ANOVAs were completed for all respiration and enzymatic data and utilized ezANOVA (Bakeman, 2005).

Sequences were returned demultiplexed from Michigan State University sequencing facility. In QIIME (version 1.9.1) the sequences were joined by multiple paired ends. The joined sequences were clustered using the open reference operational taxonomic unit (OTU) picking protocol (Rideout et al., 2014) against the Silva_128 databases for fungi and bacteria. The fungal OTUs were picked by open reference OTUs with the SILVA reference file of 99\% sequence identity. The biom table that resulted was filtered by taxonomy with a minimum count fraction of 0.00005. The table was then filtered to remove the domain of “other”. Taxonomy was assigned with the "SILVA consensus all levels 99" file and used the program mothur at 0.90 confidence. The biom file was converted to a text file for use in the qSIP process. The bacterial 16S rRNA sequences were demultiplexed and were joined by multiple paired end reads. OTUs were picked with pick_open_reference_otus at 97\% sequence identity using the Silva_128 database. Low abundance OTUs that were removed were below the minimum count fraction of 0.00005. Core diversity was rarified at a sampling depth of 10220 and the biom was converted to text for further qSIP analysis.

For qSIP analysis, the R package qSIP by Ben Koch was utilized. This package utilizes the steps and equations from Hungate et al. (2015). Excess atom fraction (EAF) ${ }^{13} \mathrm{C}$ was calculated for each OTU as described in Hungate et al. (2015). Briefly, a WAD was calculated for each OTU in each treatment. From this the mean WAD is taken and the heavier WAD (labeled isotope treatments) is subtracted by the lighter WAD (water incubated treatments). This difference is the shift in WAD. With the shift in WAD the EAF ${ }^{13} \mathrm{C}$ is calculated. The three replicates for each treatment had the average $\mathrm{EAF}{ }^{13} \mathrm{C}$ and $90 \%$ confidence intervals calculated. 


\section{Results}

Several soil characteristics differed across the litter input treatments. The depth of the organic horizon varied across treatments $(\mathrm{p}<0.001)$ with all of the treatments being significantly different from each other. The double litter treatment had the greatest organic horizon, which was almost double that of the control treatment (Table 1). The no litter treatment had less than $1 \mathrm{~cm}$ of organic horizon accumulated. The percent soil moisture for the no litter treatment had significantly greater moisture than the double litter treatment (Table 1). The WHC of the no litter and control treatments were significantly different (Tukey HSD, 0.03); the control treatment had the highest WHC of $1.00 \mathrm{~g} \mathrm{H}_{2} \mathrm{O} \mathrm{g}^{-1}$ dry soil $^{-1}$ (Table 1). The percent SOM and the C:N ratio were not significantly different between any of the treatments.

Microbial biomass analyzed by PLFA (Table 2) revealed differences in fungal and bacterial biomass. The total fungal biomass was not significantly different between treatments but was generally higher in the double litter treatment. Bacterial biomass, Actinomycetes not included, was significantly greater in the double litter treatment relative to the control and no litter treatments $(\mathrm{p}<0.05$, Table 2$)$. Actinomycetes was not included in the bacterial biomass measurement because this group has similarities to fungi and is considered a "gray" marker. The total fungal and bacterial biomass (Actinomycetes not included) and Actinomycetes biomass were similar in that the control was not significantly different from both the double and no litter treatments, but was the intermediate. The no litter treatment was significantly lower than the double litter treatment (Table 2).

To examine soil decomposition processes, soil from each treatment was incubated with ${ }^{13} \mathrm{C}$ enriched glucose and cellulose and decomposition was measured in gOM. The total C respired from soil varied by substrate, by treatment and over time (Figure 1A, C \& E). There was a difference in the amount of $\mathrm{C}$ respired in the glucose and cellulose incubations. In the cellulose incubations there was a greater total $\mathrm{C}$ respired compared to in the glucose incubations. However, a trend persisted in that the greatest total C respiration was consistently in the double litter treatment, with the control the intermediate regardless of substrate incubation. These trends are held up by statistical analysis. The cellulose incubations had the no litter and double litter treatments significantly different at the majority of time points (p-value, 0.008-0.09). No litter and double litter treatments total $C$ respiration differed significantly $(\mathrm{p}<0.001-0.07)$ in the 
glucose incubations. The glucose incubations had no litter and double litter treatments significantly different $(\mathrm{p}<0.001-0.07)$ for the majority of points. At the last time point all treatments were significantly different (Figure 1C). The control (water amended) incubations had the no litter treatment with the lowest total $\mathrm{C}$ respired. The litter incubations were not significantly different except at two times; no litter and double litter different on days 28 and 32 $(\mathrm{p}<0.04)$.

The amount of ${ }^{13} \mathrm{C}$-labeled substrate remaining varied between treatments (Figure 1 $B \& D)$. The no litter treatment had the most labeled substrate remaining in the glucose substrate incubation and it was significantly different from the control ( $\mathrm{p} 0.04$ ).

Soil extracellular enzyme activity was measured periodically throughout the incubations. There were no significant consistent trends in the data. The BG no litter and double litter treatment had differences over time with the activity rate at day 42 greater than days 0 and 7 (Table 3).

For each OTU the $\mathrm{C}$ assimilated from ${ }^{13} \mathrm{C}$ substrates was measured as the $\mathrm{EAF}^{13} \mathrm{C}$ using qSIP (Figures 2\&3). Fungal OTUs on average had an $\mathrm{EAF}^{13} \mathrm{C}$ greater than 0.1 with the exception of the double litter cellulose incubation that had an average of 0.0829 (Figure 4). Few OTUs had an $\mathrm{EAF}{ }^{13} \mathrm{C}$ greater than 0.2 (above average) and belonged to Ascomycota, Basidiomycota, Chytridiomycota, Cryptomycota and Mucoromycota, OTUs in the groups Chytridiomycota, Ascomycota and Mucoromycota had an EAF ${ }^{13} \mathrm{C}$ greater than 0.2 from glucose assimilation in at least one treatment. OTUs in Basidiomycota, Ascomycota and Mucoromycota had an $\mathrm{EAF}{ }^{13} \mathrm{C}$ greater than 0.2 from cellulose assimilation in at least one treatment. Enrichment varied across the litter treatments and there were few correlations in ${ }^{13} \mathrm{C}$ assimilation of OTUs across treatments (Figure 5). The correlations were used to compare if microbial OTUs had similar ${ }^{13} \mathrm{C}$ EAF across treatments and between treatments. The highest correlation was $r=0.42$ for the glucose double litter and control treatment. The double litter and no litter treatments had similar EAF ${ }^{13} \mathrm{C}$ for OTUs between substrates (p-value, 0.01 and 0.04 ). The total number of OTUs sequenced from each phylum was similar between substrates (Table 4). Mucoromycota and Ascomycota had the most orders sequenced across the majority of treatments and between substrates. 
Bacterial EAF ${ }^{13} \mathrm{C}$ differed by substrate. There was a greater number of OTUs that had an EAF ${ }^{13} \mathrm{C}$ greater than 0.1 in the glucose incubations than the cellulose incubations (Figure $3 \& 4$ ). Above average assimilation of the cellulose substrate was by members of Bacteroidetes and Proteobacteria (Figure 3). Bacteroidetes and Proteobacteria had the most OTUs that incorporated cellulose at an $\mathrm{EAF}{ }^{13} \mathrm{C}$ greater than 0.2 . The mean $\mathrm{EAF}{ }^{13} \mathrm{C}$ of bacterial OTUs ranged from 0.02-0.05 across the incubations (Figure 4). The lowest mean and median was for cellulose in the no litter treatment. Bacterial substrate assimilation correlated across substrates and treatments (Figure 5). All correlations had p-values $<0.001$. The greatest correlations occurred in the glucose incubations across the double litter treatment and no litter $(r=0.68)$ and control $(r=0.52)$. The lowest correlation value of 0.1 was between the cellulose double litter and glucose no litter treatment.

\section{Discussion}

\section{Soil characteristics}

After 27 years of litter manipulations the Harvard DIRT plots had few differences in soil characteristics. This trend is consistent with other DIRT plots. The amount of $\mathrm{C}$ in the mineral horizon was not significantly different between the three litter treatments and this was similar to the first 20 years of an old-growth Douglas-fir forest in Oregon and a mixed deciduous forest in Pennsylvania (Sulzman et al, 2005; Bowden et al, 2014). The first DIRT plots were established in a deciduous forest in Wisconsin. In this system soil C was significantly elevated in the double litter and reduced in the no litter compared to the control after 28 and 50 years (Lajtha et al. 2014a). The younger DIRT sites, like those in Harvard Forest, may not have a change in soil C due to a shorter period of time for $\mathrm{C}$ to sequester into the mineral soil and may take a longer period of time for sequestration to occur compared to the Wisconsin and other plots (Lajtha et al, 2014b; Fekete et al., 2014). Although soil C did not change in the mineral horizon, other soil characteristics were affected (Table 1). Specifically, the double litter treatment had lower soil moisture than the other two treatments. This could be due to the thick organic horizon in the double litter plots acting as a barrier and retaining moisture before it can reach the mineral soil. This would allow for the rainfall to evaporate off of the litter or slowly percolate through the mineral soil in the control litter treatment (Facelli \& Pickett, 1991; Sayer, 2006). 


\section{Enzymatic activity and respiration}

Extracellular enzymes like BG and CBH are responsible for the degradation of cellulose, the primary polymer in plant litter. Enzymes are considered to be the initial step of litter decomposition (Lajtha et al, 2014b, Sollins et al, 1996). Soil enzymes are deemed to be a sensitive indicator of the belowground microbial response and are used to indicate microbial nutrient demand (Dick, 1992; Gregorich et al, 1994; Jordan et al, 1995; Sinsabaugh et al, 2008). Recent studies show BG and CBH activity to increase with SOM and leaf litter (Sinsabaugh et al, 2008 \& Lajtha et al, 2014b). In 40 sites with varied ecosystems from the arctic tundra to a mixed deciduous forest excluding surface litter an increase in CBH and BG activity correlated with an increase in SOM (Sinsabaugh, 2008). In the Harvard Forest DIRT plots a similar result was observed in that BG had an increase in activity with increased amounts of leaf litter (Lajtha et al., 2014b). This correlation of increased activity with increased leaf litter and SOM did not match our data (Figure 3) in that there was no significant difference between treatments. The initial activity for BG and CBH was increased in the no litter treatment and the double litter had the lowest activity of BG. The decreased initial enzyme activity in the double litter treatments may be due to drought stress because of the low soil moisture. Drought stress has been found to decrease enzyme activity in Mediterranean forests (Sardans \& Peñuelas, 2005; Li \& Sarah, 2003; Ogaya \& Peñuelas, 2004).

The double litter treatments respired the most, and the no litter treatments respired the least regardless of glucose or cellulose addition (Figure 1). This trend is similar to ones found in Lajtha et al (2014a, 2014b) and the initial respiration measurement found in Bowden et al (1992). However, Lajtha et al (2014a) found that when respiration of C is measured per gram dry weight there was no significant difference across treatments; which was observed in our natural decomposition incubation. The control and double litter still had higher cumulative respiration rates compared to the no litter even if not significantly different (Lajtha et al, 2014a,b; Bowden et al, 1992, Crow et al., 2009). The percent ${ }^{13} \mathrm{C}$ remaining in both incubations followed the trend of the no litter treatment with an increased amount of labeled substrate remaining. In the glucose incubation the control treatment utilized a greater amount of the labeled substrate. 


\section{qSIP}

Fungal phyla and subphyla with an $\mathrm{EAF}^{13} \mathrm{C}$ greater than the average for the glucose and cellulose treatments were Mucoromycota, Kickxellomycotina, Chytridiomycota, Ascomycota and Basidiomycota. Members of these groups are known cellulose degraders and utilize glucose (Eichorst \& Kuske, 2012; Baldrian \& Valášková,, 2008; Lynd et al, 2002). The orders that were present in the soil, but did not have a high ${ }^{13} \mathrm{C}$ EAF were Archaeorhizomycetales (Ascomycota), Agaricales, Cantharelalles, Leucosporidiales, Russulales (Basidiomycota), Rhyzophlyctidales (Chytridiomycota), LKM11 (Cryptomycota), Kickxellales (Kickxellomycotina) and Mucorales (Mucoromycota). Archaeorhizomycetales is known to live close to plant roots and co-occur with the arbuscular mycorrhizae fungal group Glomerales (Choma et al., 2016). Agaricales has the capability to degrade lignin (Hanson et al., 2008) and is a soil saprobe along with the Basidiomycota orders of Cantharellales, Leucosporidiales and Russulales (Matheny et al., 2006; Veldre et al., 2013; Sampaio et al., 2003; Geml et al., 2010). Cantharellales and Russulales have members that are ectomycorrhizal symbionts (Veldre et al., 2013; Geml et al., 2010). Rhyzophlyctidales is a known soil saprobe that degrades crystalline cellulose (Gleason et al., 2011; Letcher et al., 2008). LKM11 is a parasitic order that parasitizes “zoosporic fungi” (Lara et al., 2010). The order Kickxellales can be a mycoparasite on mucoroid fungi (Humber, 2008). This order along with LKM11 would have indirect substrate usage because they have a parasitic lifestyle. Mucorales has the ability to produce chitinolytic enzymes and utilize simple carbohydrates and are known soil saprobes (Kwasna et al., 2006; Ziaee et al., 2016). All of these orders have the capability to utilize labile and recalcitrant substrates. Some of them assimilate the $\mathrm{C}$ through direct substrate usage because they have the enzymatic capacity to do so. Others assimilate $\mathrm{C}$ indirectly due to parasitic lifestyles. Some orders like Mucorales can utilize other substrates that are not cellulose or glucose.

Fungal OTUs had similar mean $\mathrm{EAF}^{13} \mathrm{C}$ between treatments and substrate incubations. This suggests that fungal OTUs are equally capable of utilizing both substrates. Fungi on average had a greater enrichment of ${ }^{13} \mathrm{C}$ (higher mean $\mathrm{EAF}{ }^{13} \mathrm{C}$ ) in both the cellulose and glucose incubations than bacteria. Bacteria had a lower mean $\mathrm{EAF}{ }^{13} \mathrm{C}$ in the cellulose incubations, especially the no litter treatment, than the glucose incubations. There were greater numbers of bacterial OTUs that were observed to have the capability to utilize glucose than cellulose. This 
was expected because in past studies it has been determined that bacterial decomposition was mostly labile substrates like glucose (De Graaff et al, 2010; de Vries \& Caruso, 2016). Many of the glucose utilizing OTUs belonged to the phyla Proteobacteria with some members of Bacteroidetes. Most of the bacteria OTUs that utilized cellulose belonged to Bacteroidetes regardless of litter treatment. Proteobacteria and Bacteroidetes OTUs are known to have cellulose and glucose degradation characteristics (Eichorst et al, 2013; Kumar \& Khanna, 2014; Lynd et al, 2002).

Bacterial OTUs had on average similar patterns in $\mathrm{C}$ assimilation (EAF ${ }^{13} \mathrm{C}$ ) between treatments and substrates. This suggests that bacterial OTUs will assimilate similar amounts of labeled-substrate regardless the history of leaf litter inputs. The strongest correlations were found between the treatments for the glucose incubations (Figure 5), which supports the majority of bacterial OTUs utilize labile substrates like glucose regardless of litter manipulation. The weaker correlations for substrate usage across treatments were for the cellulose incubations and the cellulose and glucose treatment incubations. The correlations between the treatments for cellulose and glucose were weak, which demonstrate that bacterial OTUs that are proficient at assimilating glucose are not necessarily proficient at assimilating cellulose and vice versa. Fungal OTUs were not as correlated. A trend that appears is that fungal OTUs will have similar EAF ${ }^{13} \mathrm{C}$ in the double litter and no litter treatments regardless of substrate incubation. However, the overarching trend is that fungal OTUs EAF ${ }^{13} \mathrm{C}$ varies with treatment and substrate.

The fungal community that was present in the DIRT plots varied in which OTUs had the highest $\mathrm{EAF}^{13} \mathrm{C}$ in substrate incubation and treatment. All of the phyla had member OTUs that had a high $\mathrm{EAF}{ }^{13} \mathrm{C}$ and were capable of utilizing both substrates in at least one litter input treatment. Overall, the difference in the amount of leaf litter may cause the OTUs to utilize the substrates at different rates.

For instance, some of the glucose assimilators were from phylum Basidiomycota, Ascomycota and Mucoromycota. The order Tremellales of Basidiomycota are known as cellulolytic fungi that are present in the soil (Vishniac, 2006; Nakase et al., 1996; Voř́ŕšková et al., 2014), but had some of the highest $\mathrm{EAF}^{13} \mathrm{C}$ values in the glucose no litter and control treatment incubations. Eurotiomycetes a class from Ascomycota had the highest EAF ${ }^{13} \mathrm{C}$ in the glucose control incubations. This class consists of members that are able to decompose cellulose 
and produce secondary metabolites that inhibit growth of other microorganisms in soil (Fan et al., 2012; Santamarina et al., 2002). Mortierellales from phylum Mucoromycota had the highest EAF ${ }^{13} \mathrm{C}$ in the double litter treatment. This order is mostly saprobic soil fungi and are known to utilize simple carbohydrates like glucose (Wagner et al, 2013; Kwaśna et al., 2006; Hanson et al., 2008).

The cellulose incubations had three phyla with high EAF ${ }^{13} \mathrm{C}$; Ascomycota, Mucoromycota and Chytridiomycota. In the cellulose control Umbelopsis, from order Mucorales, had an $\mathrm{EAF}^{13} \mathrm{C}$ of 0.32. Umbelopsis is known to have the capabilities to produce enzymes to degrade cellulose (Štursová et al, 2012; Baldrian et al, 2011). Another member of Mucoromycota, Endoganales and Saccharomycetales from Ascomycota were present in the no litter cellulose incubation. Order Endoganales has been known to be present in cereal fermentation and produces the enzyme BG in this process (Li et al, 2015) and have been found as saprotrophs on plant remains in soil (Yu, 2009). Saccharomycetales are known to be a soil saprobe and a "sugar fungus”. This order utilizes by-products of cellulose degradation like cellobiose and glucose (Suh et al., 2006). The increased ${ }^{13} \mathrm{C}$ EAF that is observed is due to indirect substrate usage. Another microbe is breaking down the ${ }^{13} \mathrm{C}$ - labeled cellulose substrate and Saccharomycetales has assimilated the byproducts. In the cellulose double litter incubation, Chytridiomycetes had the highest EAF ${ }^{13} \mathrm{C}$. Members of this class are found in soil and are known to be parasitic. Some members had been found to be able to degrade cellulose (Powell, 1993; Mitchell \& Deacon, 1986).

Members of Bacteroidetes and Proteobacteria dominated the degradation of cellulose and glucose respectively, and both groups have members that have the capability to degrade cellulose (Eichorst et al, 2013; Kumar \& Khanna, 2014; Bruce et al, 2010). In all cellulose substrate incubations, the members that had the greatest EAF of ${ }^{13} \mathrm{C}$ belonged to family Cytophagaceae and are known degraders of cellulose (McBride et al, 2014) and were members of genus Sporocytophaga and Cytophaga (Lynd et al, 2002; Jensen, 1940; Stanier, 1942a; Stanier, 1942b; Stursova et al, 2012). Also, Cytophagaceae demonstrated a high $\mathrm{EAF}{ }^{13} \mathrm{C}$ in the glucose incubations. Proteobacterial taxa were found in all glucose treatments and had the highest EAF ${ }^{13} \mathrm{C}$. Members of this phylum are known to utilize glucose (Fuhrer et al, 2005). Members from the families Bdellovibrionaceae and Bacteriovoracaceae were in all treatments 
and had the greatest $\mathrm{EAF}{ }^{13} \mathrm{C}$ in the glucose incubations. Bdellovibrio bacteriovorus was present in the double litter treatment and had an increased $\mathrm{EAF}^{13} \mathrm{C}$ in the cellulose control incubation. These two families have members that are predators of other microbes and have been found in forests (Rendulic et al, 2004; Tian et al, 2010; Davidov et al, 2006). A greater EAF ${ }^{13} \mathrm{C}$ in the glucose incubations by these groups can be attributed to the predation lifestyle of these microorganisms and their direct usage of the glucose substrate. By being predators these organisms may have preyed on other bacteria that utilize the labeled glucose substrate, which would increase the EAF ${ }^{13} \mathrm{C}$ for these microorganisms along with their direct consumption of glucose.

\section{Conclusion}

We found that fungal OTUs utilize cellulose and glucose on average greater than bacteria; which makes bacteria appear not as important in the degradation of cellulose and indicates they may not be better at scavenging glucose. However, the total abundance of bacteria was greater than fungi, suggesting that despite lower amounts of $\mathrm{C}$ assimilation per unit biomass their cumulative activity may have a large influence on glucose and cellulose degradation. There was a significant number of bacterial OTUs that had little or $\mathrm{no}^{13} \mathrm{C}$ assimilation, which suggest those OTUs may be dormant or utilizing alternative substrates. The other bacterial, not dormant, OTUs may be important in cellulose degradation and competitive in glucose assimilation.

Overall, litter inputs did not affect the assimilation of the $\mathrm{C}$ substrates by bacteria but did affect the ${ }^{13} \mathrm{C}$ assimilation by fungi. A pattern of similar rates in $\mathrm{EAF}{ }^{13} \mathrm{C}$ across treatments and substrate usage was observed with Proteobacteria and Bacteroidetes utilizing glucose and cellulose substrates at similar rates, respectively. Bacterial OTUs substrate usage varied with substrate and treatment with lowest usage in the cellulose no litter treatments. Fungal OTUs had few correlations between substrate and treatment. In conclusion, bacterial usage of substrates was similar regardless of the amount of litter present, whereas fungi usage may vary. 


\section{Tables}

Table 1: The mean (standard error) soil characteristics of treatment plots $(n=3)$. If treatments are similar by Tukey's HSD letters denote this. Similarities are within a column

\begin{tabular}{cccccc}
\hline Treatment & $\begin{array}{c}\text { \% Soil } \\
\text { Moisture }\end{array}$ & $\begin{array}{c}\text { \% Soil } \\
\text { Organic } \\
\text { Matter }\end{array}$ & $\begin{array}{c}\text { Water- } \\
\text { holding } \\
\text { Capacity }\end{array}$ & $\begin{array}{c}\text { Organic } \\
\text { Horizon } \\
(\mathbf{c m})\end{array}$ & C:N \\
\hline Control & 30.27 & 11.50 & 1.00 & 3.70 & 20.5 \\
& $(1.24)^{\mathrm{a}}$ & $(0.58)$ & $(0.09)^{\mathrm{a}}$ & $(0.96)^{\mathrm{a}}$ & $(0.43)$ \\
No Litter & 31.26 & 10.93 & 0.76 & 0.77 & 22.3 \\
& $(1.22)^{\mathrm{a}}$ & $(0.78)$ & $(0.02)^{\mathrm{b}}$ & $(0.48)^{\mathrm{b}}$ & $(0.79)$ \\
Double & 27.35 & 10.37 & 0.81 & 5.47 & 21.3 \\
Litter & $(0.97)^{\mathrm{b}}$ & $(0.89)$ & $(0.063)^{\mathrm{a}}$ & $(0.85)^{\mathrm{c}}$ & $(0.38)$ \\
\hline
\end{tabular}


Table 2: Effects of litter treatment on the mean relative biomass (nmol/g) of bacterial and fungal phospholipid fatty acids (standard error). If treatments are similar by Tukey's HSD this is denoted by letters. Total bacterial biomass is the sum of all general bacterial markers, gram negative and gram positive bacterial markers and does not include Actinomycetes.

\begin{tabular}{cccc}
\hline Treatment & Control & No Litter & $\begin{array}{c}\text { Double } \\
\text { Litter }\end{array}$ \\
\hline $\begin{array}{c}\text { Total fungal } \\
\text { biomass }\end{array}$ & $4.91(1.71)$ & $4.74(2.23)$ & $8.44(2.86)$ \\
$\begin{array}{c}\text { Total bacterial } \\
\text { biomass }\end{array}$ & $26.34(4.84)^{\mathrm{a}}$ & $25.75(7.89)^{\mathrm{a}}$ & $42.51(5.78)^{\mathrm{b}}$ \\
$\begin{array}{c}\text { Total fungal and } \\
\text { bacterial biomass }\end{array}$ & $31.25(6.08)^{\mathrm{a}, \mathrm{b}}$ & $30.49(9.80)^{\mathrm{b}}$ & $50.95(8.65)^{\mathrm{a}}$ \\
$\begin{array}{c}\text { Actinomycetes } \\
\text { Total }\end{array}$ & $2.93(0.75)^{\mathrm{a} . \mathrm{b}}$ & $0.88(1.53)^{\mathrm{a}}$ & $5.02(1.32)^{\mathrm{b}}$ \\
& $34.18(6.83)^{\mathrm{a}}$ & $31.37(9.30)^{\mathrm{a}}$ & $55.96(9.93)^{\mathrm{b}}$ \\
$\begin{array}{c}\text { Microbial biomass } \\
\text { Fungal:Bacterial } \\
\text { ratio }\end{array}$ & $0.17(0.03)$ & $0.18(0.03)$ & $0.17(0.02)$ \\
\hline
\end{tabular}


Table 3: Effect of litter treatment on mean enzymatic rate (nmol hr-1 $\mathrm{gOM}^{-1}$ ) of BG and CBH (standard error). If activity within a treatment and enzyme (column) over time are similar by Tukey HSD then denoted by letters.

\begin{tabular}{|c|c|c|c|c|c|c|c|}
\hline \multirow{2}{*}{\multicolumn{2}{|c|}{ Days }} & \multicolumn{3}{|c|}{ Glucose } & \multicolumn{3}{|c|}{ Cellulose } \\
\hline & & Control & No litter & Double Litter & Control & No litter & Double Litter \\
\hline \multirow{4}{*}{ 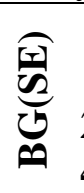 } & 0 & $2813(1005)$ & $3276(603)^{\mathrm{a}}$ & $2031(445)^{\mathrm{a}}$ & $2813(1005)$ & $3276(603)$ & 2013(445) \\
\hline & 7 & $3409(464)$ & $3607(1830)^{\mathrm{a}}$ & $2681(557)^{\mathrm{a}}$ & $2864(1002)$ & $3340(579)$ & 1995(1629) \\
\hline & 21 & 2535(412) & $3615(577)^{\mathrm{a}, \mathrm{b}}$ & $4044(1412)^{a, b}$ & 1749(331) & $3869(1176)$ & 2787(353) \\
\hline & 42 & 3106(696) & $5890(2065)^{\mathrm{b}}$ & $4401(1529)^{\mathrm{b}}$ & 2835(787) & 4743(929) & 3523(455) \\
\hline \multirow{4}{*}{ 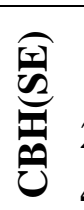 } & 0 & $311(64)$ & $500(127)$ & $369(94)$ & $311(64)$ & $500(127)$ & $369(94)$ \\
\hline & 7 & 438(181) & $338(144)$ & $320(51)$ & 239(18) & $372(109)$ & 174(137) \\
\hline & 21 & $336(20)$ & 509(158) & $265(226)$ & $180(65)$ & 391(95) & $234(57)$ \\
\hline & 42 & 406(193) & $710(224)$ & $622(413)$ & $249(71)$ & $484(140)$ & 406(137) \\
\hline
\end{tabular}


Table 4: Richness of OTUs observed within fungal orders and phyla in the different litter treatments. Category “Other” were sequences that were categorized as unknown fungi or Dikarya.

\begin{tabular}{|c|c|c|c|c|c|c|c|}
\hline \multirow[b]{3}{*}{ Phylum/Order } & \multicolumn{6}{|c|}{ \# of orders observed } & \multirow[b]{3}{*}{ Tota } \\
\hline & \multicolumn{3}{|c|}{ Glucose } & \multicolumn{3}{|c|}{ Cellulose } & \\
\hline & $\begin{array}{c}\text { No } \\
\text { Litter }\end{array}$ & Control & $\begin{array}{c}\text { Double } \\
\text { litter }\end{array}$ & $\begin{array}{l}\text { No } \\
\text { Litter }\end{array}$ & Control & $\begin{array}{c}\text { Double } \\
\text { litter }\end{array}$ & \\
\hline Ascomycota & 7 & 8 & 6 & 12 & 4 & 4 & 41 \\
\hline Archaeorhizomycetales & 2 & 3 & 2 & 2 & 0 & 0 & 9 \\
\hline Saccharomycetales & 5 & 5 & 4 & 10 & 4 & 4 & 32 \\
\hline Basidiomycota & 8 & 6 & 3 & 3 & 6 & 5 & 31 \\
\hline Agaricales & 1 & 2 & 0 & 0 & 1 & 1 & 5 \\
\hline Cantharellales & 1 & 0 & 0 & 0 & 0 & 0 & 1 \\
\hline Leucosporidiales & 2 & 0 & 0 & 0 & 1 & 0 & 3 \\
\hline Russulales & 1 & 1 & 0 & 0 & 1 & 1 & 4 \\
\hline Tremellales & 3 & 3 & 3 & 3 & 3 & 3 & 18 \\
\hline Chytridiomycota & 3 & 3 & 1 & 3 & 4 & 3 & 17 \\
\hline Chytridiales & 3 & 2 & 1 & 3 & 4 & 3 & 16 \\
\hline Rhizophlyctidales & 0 & 1 & 0 & 0 & 0 & 0 & 1 \\
\hline Cryptomycota & 4 & 2 & 4 & 6 & 4 & 4 & 24 \\
\hline LKM11 & 4 & 2 & 4 & 6 & 4 & 4 & 24 \\
\hline Kickxellomycotina & 3 & 1 & 2 & 2 & 0 & 3 & 11 \\
\hline Kickxellales & 3 & 1 & 2 & 2 & 0 & 3 & 11 \\
\hline Mucoromycota & 18 & 22 & 21 & 20 & 22 & 18 & 121 \\
\hline Endogonales & 2 & 2 & 2 & 3 & 2 & 2 & 13 \\
\hline Mortierellales & 10 & 12 & 12 & 9 & 13 & 10 & 66 \\
\hline Mucorales & 6 & 8 & 7 & 8 & 7 & 6 & 42 \\
\hline Other & 8 & 5 & 5 & 6 & 6 & 6 & 36 \\
\hline
\end{tabular}




\section{Figures}

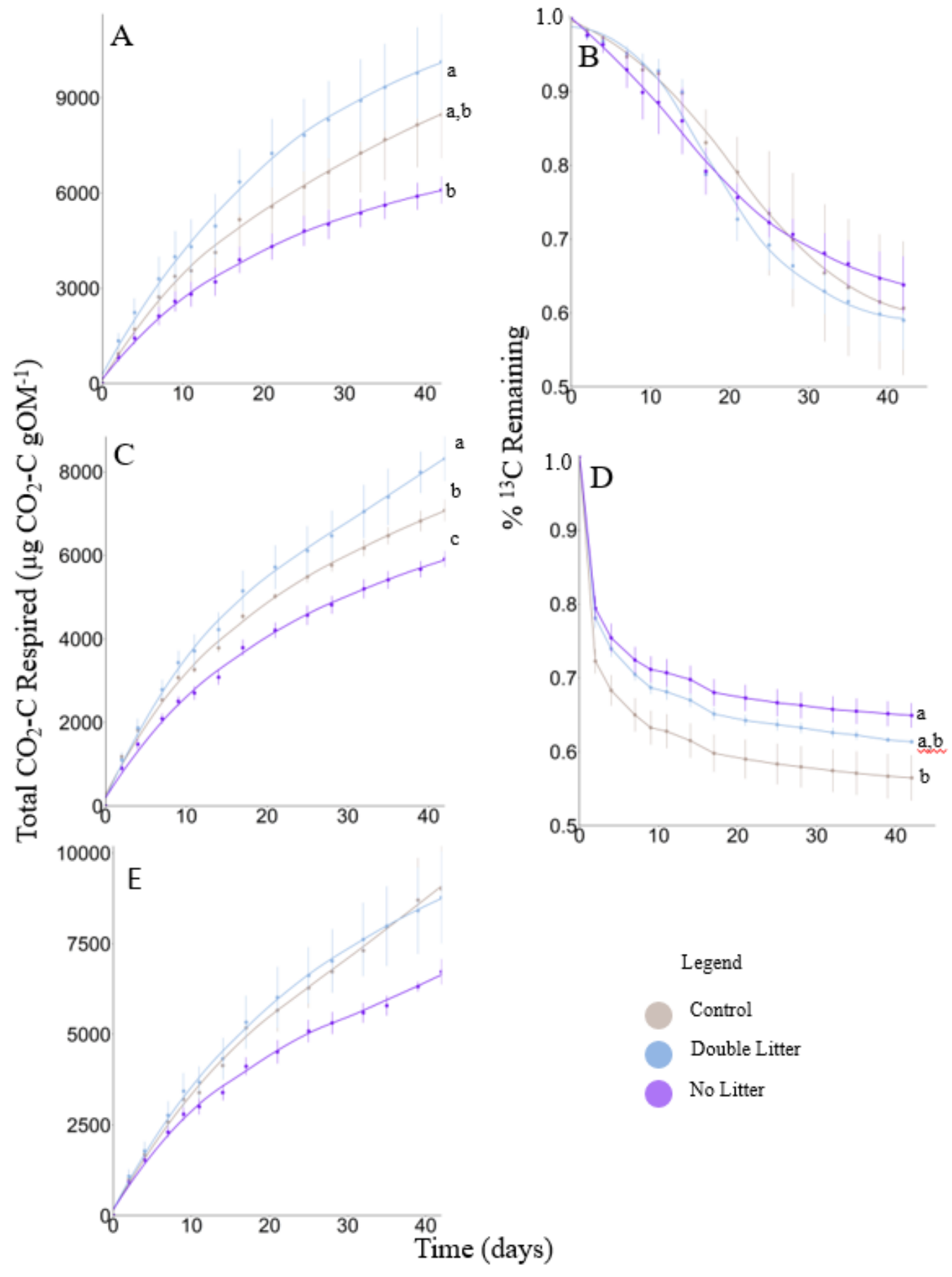

Figure 1: The effect of historical detrital input on cellulose (A\&B), glucose (C\&D) and natural (E) decomposition. Cumulative soil respiration showing the mean (SE) total carbon respired (A, C \& E) and the percent ${ }^{13} \mathrm{C}$-labeled substrates remaining (B\&D). Two-way repeated ANOVA and Tukey HSD are represented by lower case letters. Significant differences on day 42 are denoted with lower case letters. 

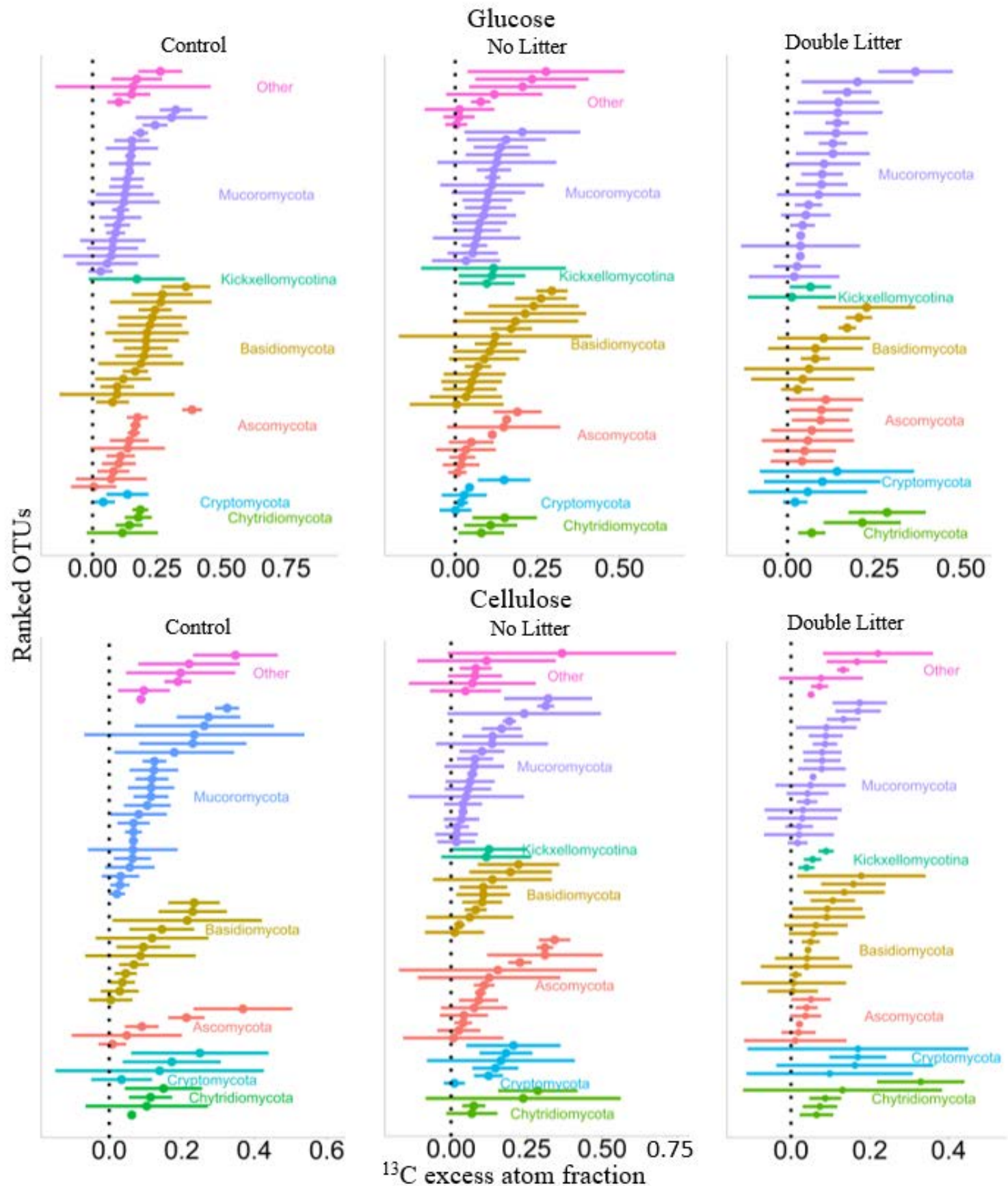

Figure 2: Fungal OTU-specific atom fraction excess of ${ }^{13} \mathrm{C}$ in the glucose (top row) and cellulose (bottom row) incubations. Shifts are caused by the assimilation of the labeled substrate into DNA in the control (left), no litter (middle) and double litter (right) treatments. Bars show medians and 90\% CIs. 

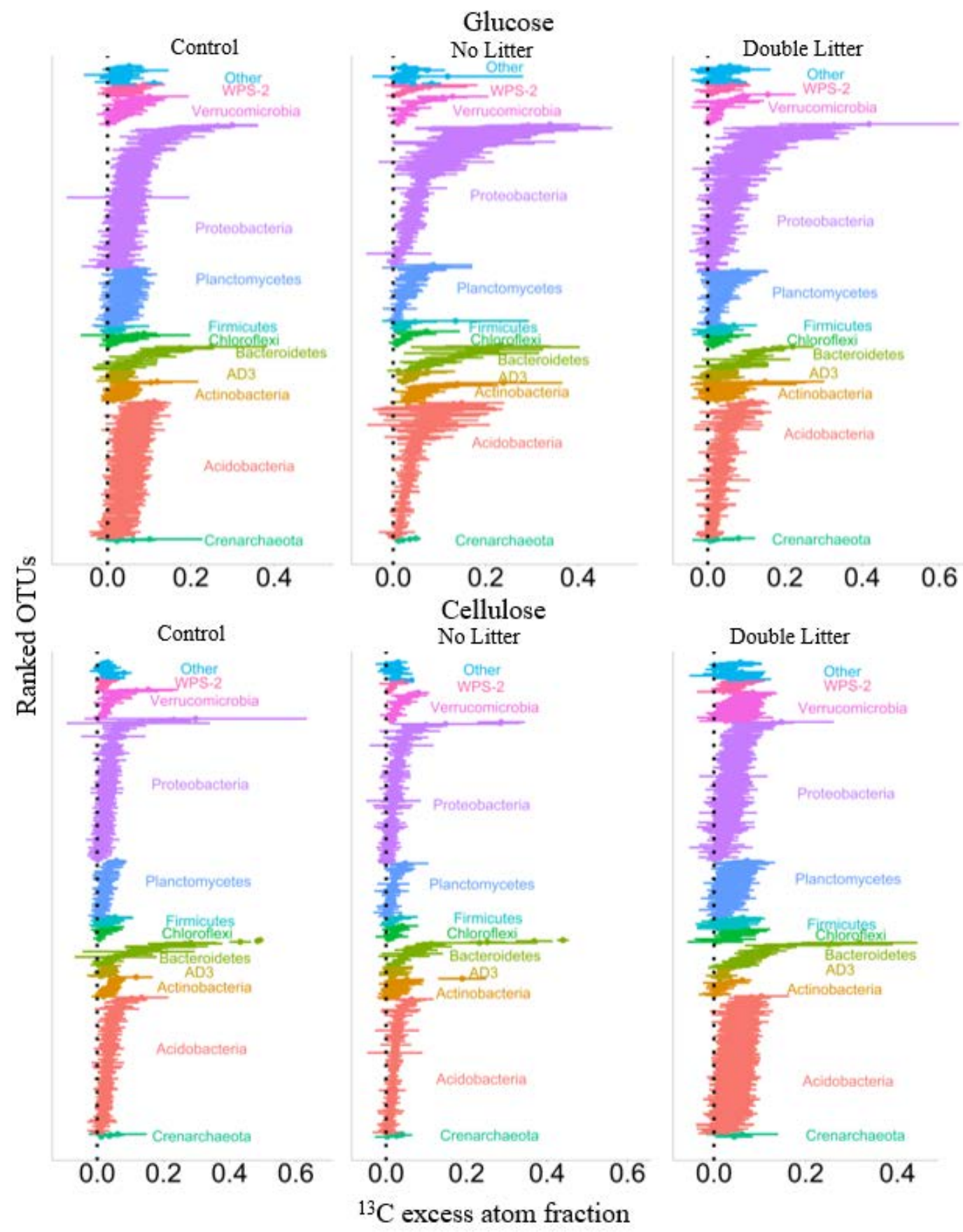

Figure 3: Bacterial OTU-specific atom fraction excess ${ }^{13} \mathrm{C}$ in the glucose (top row) and cellulose (bottom row) incubations. Shifts are caused by the assimilation of the labeled substrate into DNA in the control (left), no litter (middle) and double litter (right) treatments. Bars show medians and 90\% CIs. 


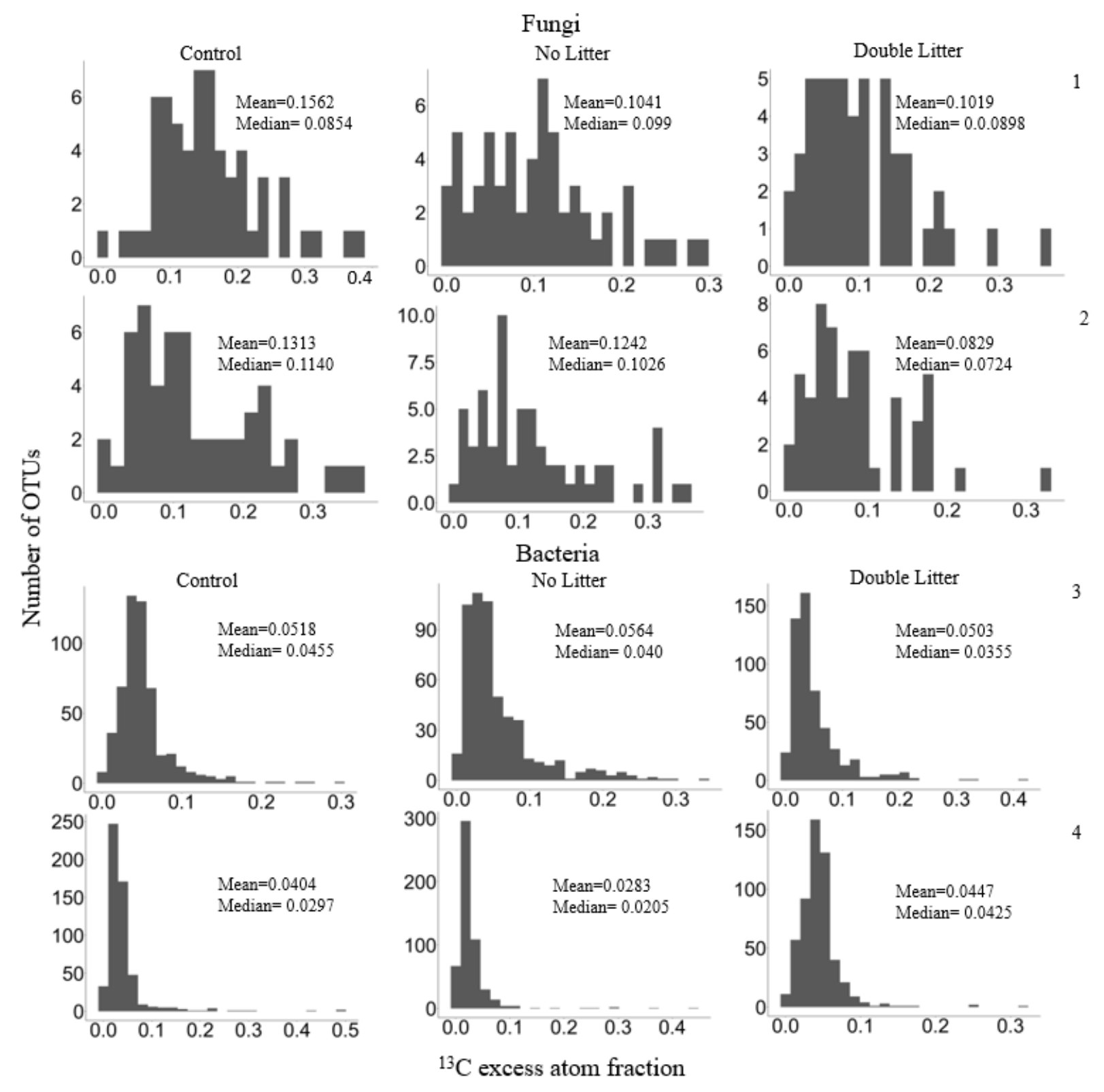

Figure 4: Histograms of atom fraction excess of ${ }^{13} \mathrm{C}$ for fungal (Rows $1 \& 2$ ) and bacterial OTUs (Rows 3\&4) in the glucose (Rows 1\&3) and cellulose (Rows 2\&4) incubations. Treatments are organized by column; control (left), no litter (middle) and double (right). 


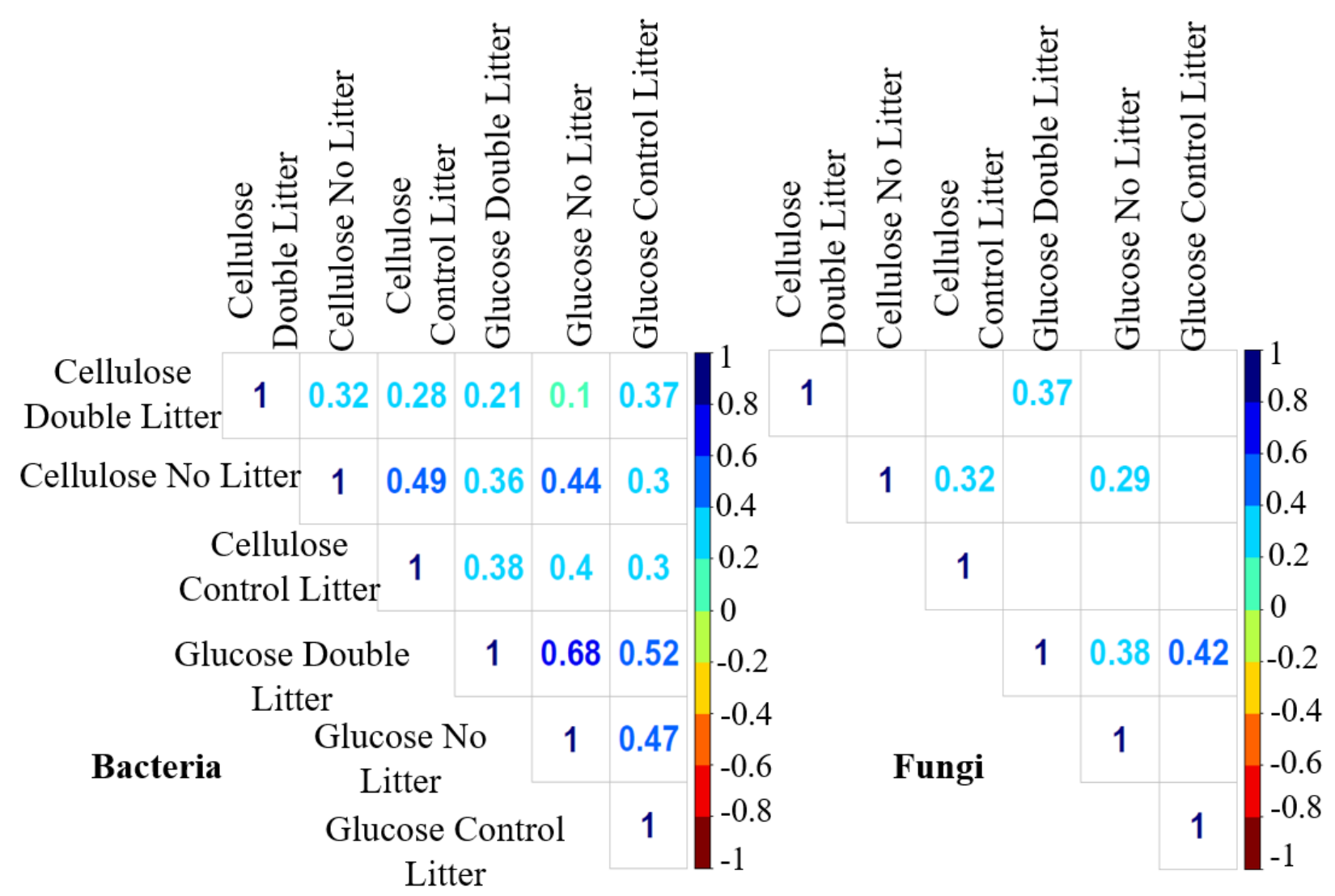

Figure 5: Spearman correlation of atom fraction excess of ${ }^{13} \mathrm{C}$ across treatments. Only correlations with a significant p-value shown. Bacterial correlations (left) had significant correlations between treatments and substrates. Fungal correlations (right) only had a few significant correlations. 


\section{References}

Allison, S. D. (2012). A trait-based approach for modelling microbial litter decomposition. Ecology Letters, 15(9), 1058-1070.

Averill, C., Turner, B. L., \& Finzi, A. C. (2014). Mycorrhiza-mediated competition between plants and decomposers drives soil carbon storage. Nature, 505(7484), 543.

Bååth, E. (2003). The use of neutral lipid fatty acids to indicate the physiological conditions of soil fungi. Microbial Ecology, 45(4), 373-383

Bakeman, R. (2005). Recommended effect size statistics for repeated measures designs. Behavior Research Methods, 37(3), 379-384.

Baldrian, P., Kolařík, M., Štursová, M., Kopecký, J., Valášková, V., Větrovský, T., ... \& Voříšková, J. (2012). Active and total microbial communities in forest soil are largely different and highly stratified during decomposition. The ISME journal, 6(2), 248.

Baldrian, P., \& Valášková, V. (2008). Degradation of cellulose by basidiomycetous fungi. FEMS microbiology reviews, 32(3), 501-521.

Baldrian, P., Vořŕšková, J., Dobiášová, P., Merhautová, V., Lisá, L., \& Valášková, V. (2011).

Production of extracellular enzymes and degradation of biopolymers by saprotrophic microfungi from the upper layers of forest soil. Plant and Soil, 338(1-2), 111-125.

Bardgett, R.D., Hobbs, P.J. and Frostegårde, A. (1996). Changes in soil fungal:bacterial biomass ratios following reductions in the intensity of management of an upland grassland. Biology and Fertility of Soils 22(3), 261-264

Bezemer, T. M., Fountain, M. T., Barea, J. M., Christensen, S., Dekker, S. C., Duyts, H., ... \& Mikola, J. (2010). Divergent composition but similar function of soil food webs of individual plants: plant species and community effects. Ecology, 91(10), 3027-3036.

Bligh, E.G. and Dyer, W.J. (1959). A rapid method of total lipid extraction and purification. Canadian Journal of Biochemistry and Physiology, 37(8), 911-917

Bowden, R. D., Deem, L., Plante, A. F., Peltre, C., Nadelhoffer, K., \& Lajtha, K. (2014). Litter input controls on soil carbon in a temperate deciduous forest. Soil Science Society of America Journal, 78(S1), S66-S75.

Bowden, R. D., Nadelhoffer, K. J., Boone, R. D., Melillo, J. M., \& Garrison, J. B. (1993). Contributions of aboveground litter, belowground litter, and root respiration to total soil respiration in a temperate mixed hardwood forest. Canadian Journal of Forest Research, 23(7), 1402-1407.

Bruce, T., Martinez, I. B., Neto, O. M., Vicente, A. C. P., Kruger, R. H., \& Thompson, F. L. (2010). Bacterial community diversity in the Brazilian Atlantic forest soils. Microbial ecology, 60(4), 840-849.

Chambers, J. M., Freeny, A and Heiberger, R. M. (1992). Statistical Models in S. New York: Routledge. 
Choma, M., Bárta, J., Šantrůčková, H., \& Urich, T. (2016). Low abundance of Archaeorhizomycetes among fungi in soil metatranscriptomes. Scientific reports, 6, 38455.

Cotrufo, M. F., Wallenstein, M. D., Boot, C. M., Denef, K., \& Paul, E. (2013). The Microbial Efficiency-Matrix Stabilization (MEMS) framework integrates plant litter decomposition with soil organic matter stabilization: do labile plant inputs form stable soil organic matter?. Global Change Biology, 19(4), 988-995.

Couteaux, M. M., Bottner, P., \& Berg, B. (1995). Litter decomposition, climate and liter quality. Trends in ecology \& evolution, 10(2), 63-66.

Crow, S. E., Lajtha, K., Bowden, R. D., Yano, Y., Brant, J. B., Caldwell, B. A., \& Sulzman, E. W. (2009). Increased coniferous needle inputs accelerate decomposition of soil carbon in an oldgrowth forest. Forest Ecology and Management, 258(10), 2224-2232.

Davidov, Y., Friedjung, A., \& Jurkevitch, E. (2006). Structure analysis of a soil community of predatory bacteria using culture-dependent and culture-independent methods reveals a hitherto undetected diversity of Bdellovibrio-and-like organisms. Environmental Microbiology, 8(9), 1667-1673.

de Graaff, M. A., Classen, A. T., Castro, H. F., \& Schadt, C. W. (2010). Labile soil carbon inputs mediate the soil microbial community composition and plant residue decomposition rates. New Phytologist, 188(4), 1055-1064.

de Ruiter, P. C., Moore, J. C., Zwart, K. B., Bouwman, L. A., Hassink, J., Bloem, J., ... \& Brussaard, L. (1993). Simulation of nitrogen mineralization in the below-ground food webs of two winter wheat fields. Journal of Applied Ecology, 30(1), 95-106.

de Vries, F. T., \& Caruso, T. (2016). Eating from the same plate? Revisiting the role of labile carbon inputs in the soil food web. Soil Biology and Biochemistry, 102, 4-9.

de Vries, F. T., Van Groenigen, J. W., Hoffland, E., \& Bloem, J. (2011). Nitrogen losses from two grassland soils with different fungal biomass. Soil Biology and Biochemistry, 43(5), 997-1005.

Dick, R. P. (1992). A review: long-term effects of agricultural systems on soil biochemical and microbial parameters. Biotic Diversity in Agroecosystems, 25-36.

el Zahar Haichar, F., Achouak, W., Christen, R., Heulin, T., Marol, C., Marais, M. F., ... \& Berge, O. (2007). Identification of cellulolytic bacteria in soil by stable isotope probing. Environmental Microbiology, 9(3), 625-634.

Eichorst, S. A., \& Kuske, C. R. (2012). Identification of cellulose-responsive bacterial and fungal communities in geographically and edaphically different soils by using stable isotope probing. Applied and environmental microbiology, 78(7), 2316-2327.

Eichorst, S. A., Varanasi, P., Stavila, V., Zemla, M., Auer, M., Singh, S., ... \& Singer, S. W. (2013). Community dynamics of cellulose-adapted thermophilic bacterial consortia. Environmental microbiology, 15(9), 2573-2587. 
Ekelund, F., Olsson, S. and Johansen, A. (2003). Changes in the succession and diversity of protozoan and microbial populations in soil spiked with a range of copper concentrations. Soil Biology and Biochemistry, 35(11), 1507-1516

Evans, S. E., \& Wallenstein, M. D. (2014). Climate change alters ecological strategies of soil bacteria. Ecology letters, 17(2), 155-164.

Facelli, J. M., \& Pickett, S. T. (1991). Plant litter: its dynamics and effects on plant community structure. The botanical review, 57(1), 1-32.

Fan, F., Li, Z., Wakelin, S. A., Yu, W., \& Liang, Y. (2012). Mineral fertilizer alters cellulolytic community structure and suppresses soil cellobiohydrolase activity in a long-term fertilization experiment. Soil Biology and Biochemistry, 55, 70-77.

Fierer, N., Schimel, J. P., \& Holden, P. A. (2003). Variations in microbial community composition through two soil depth profiles. Soil Biology and Biochemistry, 35(1), 167-176.

Fekete, I., Kotroczó, Z., Varga, C., Nagy, P. T., Várbíró, G., Bowden, R. D., ... \& Lajtha, K. (2014). Alterations in forest detritus inputs influence soil carbon concentration and soil respiration in a Central-European deciduous forest. Soil Biology and Biochemistry, 74, 106-114.

Fontaine, S., Barot, S., Barré, P., Bdioui, N., Mary, B., \& Rumpel, C. (2007). Stability of organic carbon in deep soil layers controlled by fresh carbon supply. Nature, 450(7167), 277-280.

Fuhrer, T., Fischer, E., \& Sauer, U. (2005). Experimental identification and quantification of glucose metabolism in seven bacterial species. Journal of bacteriology, 187(5), 1581-1590.

Geml, J., Laursen, G. A., Herriott, I. C., McFarland, J. M., Booth, M. G., Lennon, N., ... \& Taylor, D. L. (2010). Phylogenetic and ecological analyses of soil and sporocarp DNA sequences reveal high diversity and strong habitat partitioning in the boreal ectomycorrhizal genus Russula (Russulales; Basidiomycota). New Phytologist, 187(2), 494-507.

Gleason, F. H., Marano, A. V., Digby, A. L., Al-Shugairan, N., Lilje, O., Steciow, M. M., ... \& Nakagiri, A. (2011). Patterns of utilization of different carbon sources by Chytridiomycota. Hydrobiologia, 659(1), 55-64.

Gregorich, E. G., Monreal, C. M., Carter, M. R., Angers, D. A., \& Ellert, B. (1994). Towards a minimum data set to assess soil organic matter quality in agricultural soils. Canadian journal of soil science, 74(4), 367-385.

Guckert, J.B., Antworth, C.P. and Nichols, P.D. (1985). Phospholipid, ester-linked fatty acid profiles as reproducible assays for changes in prokaryotic community structure of estuarine sediments. FEMS Microbiology Ecology, 31(3),147-158

Hanson, C. A., Allison, S. D., Bradford, M. A., Wallenstein, M. D., \& Treseder, K. K. (2008). Fungal taxa target different carbon sources in forest soil. Ecosystems, 11(7), 1157-1167.

Humber, R. A. (2008). Evolution of entomopathogenicity in fungi. Journal of invertebrate pathology, 98(3), 262-266. 
Hungate, B. A., Mau, R. L., Schwartz, E., Caporaso, J. G., Dijkstra, P., van Gestel, N., ... \& Morrissey, E. M. (2015). Quantitative microbial ecology through stable isotope probing. Applied and environmental microbiology, 81(21), 7570-7581.

Hunt, H. W., Coleman, D. C., Ingham, E. R., Ingham, R. E., Elliott, E. T., Moore, J. C., ... \& Morley, C. R. (1987). The detrital food web in a shortgrass prairie. Biology and Fertility of Soils, 3(1), 5768.

Jensen, H. L. (1940). Nitrogen fixation and cellulose decomposition by soil microorganisms. I. Aerobic cellulose-decomposers in association with azotobacter. Proceedings of the Linnean Society of New South Wales, 65, 543-556.

Jordan, D., Kremer, R. J., Bergfield, W. A., Kim, K. Y., \& Cacnio, V. N. (1995). Evaluation of microbial methods as potential indicators of soil quality in historical agricultural fields. Biology and Fertility of Soils, 19(4), 297-302.

Kozich, J. J., Westcott, S. L., Baxter, N. T., Highlander, S. K., \& Schloss, P. D. (2013). Development of a dual-index sequencing strategy and curation pipeline for analyzing amplicon sequence data on the MiSeq Illumina sequencing platform. Applied and environmental microbiology, 79(17), 5112-5120.

Kramer, C., \& Gleixner, G. (2008). Soil organic matter in soil depth profiles: distinct carbon preferences of microbial groups during carbon transformation. Soil Biology and Biochemistry, 40(2), 425433.

Kumar, M., \& Khanna, S. (2014). Shift in microbial population in response to crystalline cellulose degradation during enrichment with a semi-desert soil. International Biodeterioration \& Biodegradation, 88, 134-141.

Kwaśna, H., Elaine, W. A. R. D., \& Bateman, G. L. (2006). Phylogenetic relationships among Zygomycetes from soil based on ITS1/2 rDNA sequences. Mycological research, 110(5), 501510.

Lal, R. (2004). Soil carbon sequestration to mitigate climate change. Geoderma, 123(1), 1-22.

Lajtha, K., Townsend, K. L., Kramer, M. G., Swanston, C., Bowden, R. D., \& Nadelhoffer, K. (2014a). Changes to particulate versus mineral-associated soil carbon after 50 years of litter manipulation in forest and prairie experimental ecosystems. Biogeochemistry, 119(1-3), 341-360.

Lajtha, K., Bowden, R. D., \& Nadelhoffer, K. (2014b). Litter and root manipulations provide insights into soil organic matter dynamics and stability. Soil Science Society of America Journal, 78(S1), S261-S269.

Lara, E., Moreira, D., \& López-García, P. (2010). The environmental clade LKM11 and Rozella form the deepest branching clade of fungi. Protist, 161(1), 116-121.

Leckie, S.E., Prescott, C.E. and Grayston, S.J. (2004). Comparison of chloroform-fumigation extraction, phospholipid fatty acid, and DNA methods to determine microbial biomass in forest humus. Soil Biology and Biochemistry, 36(3), 529-532. 
Lehmann, J., \& Kleber, M. (2015). The contentious nature of soil organic matter. Nature, 528(7580), 60.

Letcher, P. M., Powell, M. J., Barr, D. J., Churchill, P. F., Wakefield, W. S., \& Picard, K. T. (2008). Rhizophlyctidales - a new order in Chytridiomycota. Mycological research, 112(9), 1031-1048.

Li, P., Liang, H., Lin, W. T., Feng, F., \& Luo, L. (2015). Microbiota dynamics associated with environmental conditions and potential roles of cellulolytic communities in traditional Chinese cereal starter solid-state fermentation. Applied and environmental microbiology, 81(15), 51445156.

Li, X., \& Sarah, P. (2003). Enzyme activities along a climatic transect in the Judean Desert. Catena, 53(4), 349-363.

Lopez-Lozano, N. E., Heidelberg, K. B., Nelson, W. C., García-Oliva, F., Eguiarte, L. E., \& Souza, V. (2013). Microbial secondary succession in soil microcosms of a desert oasis in the Cuatro Cienegas Basin, Mexico. PeerJ, 1, e47.

Lu, W. J., Wang, H. T., Yang, S. J., Wang, Z. C., \& Nie, Y. F. (2005). Isolation and characterization of mesophilic cellulose-degrading bacteria from flower stalks-vegetable waste co-composting system. The Journal of general and applied microbiology, 51(6), 353-360.

Lynd, L. R., Weimer, P. J., Van Zyl, W. H., \& Pretorius, I. S. (2002). Microbial cellulose utilization: fundamentals and biotechnology. Microbiology and molecular biology reviews, 66(3), 506-577.

Matheny, P. B., Curtis, J. M., Hofstetter, V., Aime, M. C., Moncalvo, J. M., Ge, Z. W., ... \& Bougher, N. L. (2006). Major clades of Agaricales: a multilocus phylogenetic overview. Mycologia, 98(6), 982-995.

McBride, M. J., Liu, W., Lu, X., Zhu, Y., \& Zhang, W. (2014). The family cytophagaceae. The Prokaryotes, 577-593. Springer Berlin Heidelberg.

McKinley, D. C., Ryan, M. G., Birdsey, R. A., Giardina, C. P., Harmon, M. E., Heath, L. S., ... \& Pataki, D. E. (2011). A synthesis of current knowledge on forests and carbon storage in the United States. Ecological applications, 21(6), 1902-1924.

Mitchell, R. T., \& Deacon, J. W. (1986). Selective accumulation of zoospores of Chytridiomycetes and Oomycetes on cellulose and chitin. Transactions of the British Mycological Society, 86(2), 219223.

Morrissey, E. M., Gillespie, J. L., Morina, J. C., \& Franklin, R. B. (2014). Salinity affects microbial activity and soil organic matter content in tidal wetlands. Global change biology, 20(4), 13511362.

Morrissey, E. M., McHugh, T. A., Preteska, L., Hayer, M., Dijkstra, P., Hungate, B. A., \& Schwartz, E. (2015). Dynamics of extracellular DNA decomposition and bacterial community composition in soil. Soil Biology and Biochemistry, 86, 42-49.

Nadelhoffer, K., Bowden, R., Boone, R., \& Lajtha, K. (1999). Controls on forest soil organic matter development and dynamics, chronic litter manipulation as a potential international LTER 
activity. Cooperation in long term ecological research in central and eastern Europe, proceedings of the ILTER regional workshop, 22-25.

Nakase, T., Suzuki, M., Hamamoto, M., Takashima, M., Hatano, T., \& Fukui, S. (1996). A taxonomic study on cellulolytic yeasts and yeast-like microorganisms isolated in Japan. II. The genus Cryptococcus. The Journal of General and Applied Microbiology, 42(1), 7-15.

Neubauer, S. C., Franklin, R. B., \& Berrier, D. J. (2013). Saltwater intrusion into tidal freshwater marshes alters the biogeochemical processing of organic carbon. Biogeosciences, 10(12), 8171.

Ogaya, R., \& Peñuelas, J. (2004). Phenological patterns of Quercus ilex, Phillyrea latifolia, and Arbutus unedo growing under a field experimental drought. Ecoscience, 11(3), 263-270.

Philippot, L., Raaijmakers, J. M., Lemanceau, P., \& Van Der Putten, W. H. (2013). Going back to the roots: the microbial ecology of the rhizosphere. Nature Reviews Microbiology, 11(11), 789.

Powell, M. J. (1993). Looking at mycology with a Janus face: a glimpse at Chytridiomycetes active in the environment. Mycologia, 85(1), 1-20.

Ransom-Jones, E., Jones, D. L., McCarthy, A. J., \& McDonald, J. E. (2012). The Fibrobacteres: an important phylum of cellulose-degrading bacteria. Microbial ecology, 63(2), 267-281.

Rendulic, S., Jagtap, P., Rosinus, A., Eppinger, M., Baar, C., Lanz, C., ... \& Meyer, F. (2004). A predator unmasked: life cycle of Bdellovibrio bacteriovorus from a genomic perspective. Science, 303(5658), 689-692.

Rey, A., Petsikos, C., Jarvis, P. G., \& Grace, J. (2005). Effect of temperature and moisture on rates of carbon mineralization in a Mediterranean oak forest soil under controlled and field conditions. European Journal of Soil Science, 56(5), 589-599.

Rideout, J. R., He, Y., Navas-Molina, J. A., Walters, W. A., Ursell, L. K., Gibbons, S. M., ... \& Clemente, J. C. (2014). Subsampled open-reference clustering creates consistent, comprehensive OTU definitions and scales to billions of sequences. PeerJ, 2, e545.

Rousk, J., \& Frey, S. D. (2015). Revisiting the hypothesis that fungal-to-bacterial dominance characterizes turnover of soil organic matter and nutrients. Ecological Monographs, 85(3), 457472.

Sampaio, J. P., Gadanho, M., Bauer, R., \& Weiß, M. (2003). Taxonomic studies in the Microbotryomycetidae: Leucosporidium golubevii sp. nov., Leucosporidiella gen. nov. and the new orders Leucosporidiales and Sporidiobolales. Mycological Progress, 2(1), 53-68.

Santamarina, M. P., Roselló, J., Llacer, R., \& Sanchis, V. (2002). Antagonistic activity of Penicillium oxalicum Corrie and Thom, Penicillium decumbens Thom and Trichoderma harzianum Rifai isolates against fungi, bacteria and insects in vitro. Revista iberoamericana de micología, 19(2), 99-103.

Sardans, J., \& Peñuelas, J. (2005). Drought decreases soil enzyme activity in a Mediterranean Quercus ilex L. forest. Soil Biology and Biochemistry, 37(3), 455-461. 
Sariyildiz, T., \& Anderson, J. M. (2003). Interactions between litter quality, decomposition and soil fertility: a laboratory study. Soil Biology and Biochemistry, 35(3), 391-399.

Sayer, E. J. (2006). Using experimental manipulation to assess the roles of leaf litter in the functioning of forest ecosystems. Biological reviews, 81(1), 1-31.

Sinsabaugh, R. L., Lauber, C. L., Weintraub, M. N., Ahmed, B., Allison, S. D., Crenshaw, C., ... \& Gartner, T. B. (2008). Stoichiometry of soil enzyme activity at global scale. Ecology letters, 11(11), 1252-1264.

Šnajdr, J., Valášková, V., Merhautová, V., Herinková, J., Cajthaml, T., \& Baldrian, P. (2008). Spatial variability of enzyme activities and microbial biomass in the upper layers of Quercus petraea forest soil. Soil Biology and Biochemistry, 40(9), 2068-2075.

Sollins, P., Homann, P., \& Caldwell, B. A. (1996). Stabilization and destabilization of soil organic matter: mechanisms and controls. Geoderma, 74(1-2), 65-105.

Stanier, R. Y. (1942a). Are there obligate cellulose-decomposing bacteria?. Soil Science, 53(6), 479-480.

Stanier, R. Y. (1942b). The Cytophaga group: a contribution to the biology of myxobacteria. Bacteriological reviews, 6(3), 143.

Štursová, M., Žifč́áková, L., Leigh, M. B., Burgess, R., \& Baldrian, P. (2012). Cellulose utilization in forest litter and soil: identification of bacterial and fungal decomposers. FEMS microbiology ecology, 80(3), 735-746.

Suh, S. O., Blackwell, M., Kurtzman, C. P., \& Lachance, M. A. (2006). Phylogenetics of Saccharomycetales, the ascomycete yeasts. Mycologia, 98(6), 1006-1017.

Sulzman, E. W., Brant, J. B., Bowden, R. D., \& Lajtha, K. (2005). Contribution of aboveground litter, belowground litter, and rhizosphere respiration to total soil CO 2 efflux in an old growth coniferous forest. Biogeochemistry, 73(1), 231-256.

Tian, B. Y., Huang, Q. G., Xu, Y., Wang, C. X., Lv, R. R., \& Huang, J. Z. (2010). Microbial community structure and diversity in a native forest wood-decomposed hollow-stump ecosystem. World Journal of Microbiology and Biotechnology, 26(2), 233-240.

Torsvik, V., \& Øvreås, L. (2002). Microbial diversity and function in soil: from genes to ecosystems. Current opinion in microbiology, 5(3), 240-245.

Veldre, V., Abarenkov, K., Bahram, M., Martos, F., Selosse, M. A., Tamm, H., ... \& Tedersoo, L. (2013). Evolution of nutritional modes of Ceratobasidiaceae (Cantharellales, Basidiomycota) as revealed from publicly available ITS sequences. Fungal Ecology, 6(4), 256-268.

Vishniac, H. S. (2006). A multivariate analysis of soil yeasts isolated from a latitudinal gradient. Microbial ecology, 52(1), 90-103.

Voř́šková, J., Brabcová, V., Cajthaml, T., \& Baldrian, P. (2014). Seasonal dynamics of fungal communities in a temperate oak forest soil. New Phytologist, 201(1), 269-278. 
Wagner, L., Stielow, B., Hoffmann, K., Petkovits, T., Papp, T., Vágvölgyi, C., ... \& Voigt, K. (2013). A comprehensive molecular phylogeny of the Mortierellales (Mortierellomycotina) based on nuclear ribosomal DNA. Persoonia: Molecular Phylogeny and Evolution of Fungi, 30, 77.

Waring, B. G., Averill, C., \& Hawkes, C. V. (2013). Differences in fungal and bacterial physiology alter soil carbon and nitrogen cycling: Insights from meta-analysis and theoretical models. Ecology letters, 16(7), 887-894.

White, D.C., Davis, W.M., Nickels, J.S., King, J.S. and Bobbie, R.J. (1979). Determination of the sedimentary microbial biomass by extractable lipid phosphate. Oecologia, 40(1), 51-62.

Yu, C. I. (2009). Soil biota. Environmental Structure and Function: Earth System, 167, Oxford, United Kingdom:EOLSS Publications.

Zhang, Y., Cong, J., Lu, H., Yang, C., Yang, Y., Zhou, J., \& Li, D. (2014). An integrated study to analyze soil microbial community structure and metabolic potential in two forest types. PloS one, 9(4), e93773.

Ziaee, A., Zia, M., Bayat, M., \& Hashemi, J. (2016). Identification of Mucorales isolates from soil using morphological and molecular methods. Current medical mycology, 2(1),13. 